\title{
De tyske privatskoler i Skærbæk og Gånsager 1930-45
}

\author{
af H.E. SøRENSEN
}

I 1930 åbnede en tysk privatskole i Skærbæk, og i 1932 fulgte nabolandsbyen Gånsager efter. Over hele Nordslesvig oprettedes mellem 1920 og $1945 \mathrm{i}$ alt 65 tyske privatskoler, hvortil kom 35 kommuneskoler med tyske klasser. Skolerne dannede en hovedhjørnesten i det tyske arbejde i landsdelen, på godt og ondt. Museumsleder og forfatter H. E. Sørensen, Skærbæk, har fremdraget et stort kildemateriale om de to Skærbæk-skoler. Hans beretning illustrerer mange af de træk, som $i$ almindelighed var typiske for mindretalsskolernes opståen og historie $\mathrm{i}$ årene frem til det tyske sammenbrud $\mathrm{i} 1945$.

\section{Det første forsøg}

I 1932 bad lederen af den tyske privatskole i Skærbæk, Andreas Rahlf, lærer Herluf Löch, Helgoland, om oplysninger om begyndelsen til det tyske skolearbejde i Skærbæk efter Genforeningen.

Löch var en af de første, der tog et tysk undervisningsarbejde op i landdistrikterne i den »afståede« landsdel. I alt seks lærere blev allerede i 1919 udpeget til dette arbejde, to i Aabenraa amt og fire i Haderslev amt. Blandt dem var Herluf Löch og Lydia Wohlenberg, som begge kom til at virke på Skærbækegnen.

Löch fik de nordvestlige egne som ansvarsområde. Her var ofte langt mellem de tyske familier. Han begyndte i juni 1921 i Toftlund, hvor den første vandreskole opstod; kort efter kom der en i ArnumHøjrup, fortæller han i brevet til Rahlf. Det vil sige, at de børn, som var tilmeldt skolen, samledes en eftermiddag eller to om ugen (efter dansk skoletid) som oftest $i$ et privat hjem, hvor vandrelæreren underviste i tysk ved at læse og skrive med dem, snakke med dem og lære dem en smule om tysk historie og kultur. Læreren kom omkring i sit distrikt på cykel, og han skulle nå mindst et nyt sted hver dag.

"Fra Toftlund søgte jeg i 1922 kontakt med tyske i Skærbæk", fortsatte Löch. »På slagtermester Skaus initiativ lykkedes det at indrette en vandreskole i Skærbæk - jeg tror det var i 1923. Undervisningen fandt sted for 7-10 børn i en stue i Skaus hus, som regel en gang om 
ugen. Før oprettelsen af skolen havde der været en sammenkomst med de tyske i Banegårdsrestauranten (Stehr). Hvis jeg ikke husker fejl, var der også en gang et besøg fra Kiel i Skærbæk. Vandreskoleundervisningen gik en tid lang godt fremad til stor ærgrelse for danskerne, indtil det lykkedes læge Lausten-Thomsen at fremtvinge en lukning - af sundhedsmæssige grunde. Det var i slutningen af 1923 - eller begyndelsen af 1924 . Fra mit nye bosted Rødding besøgte jeg derefter kun sjældent Skærbæk og kom da hos Skaus. At samle alle Skærbæk-tyskere til en ny fælles indsats var ikke mere muligt. Om det lykkedes at afholde en tysk aften i Skærbæk - som det skete i Toftlund, Arnum, Rødding og Jels - er gledet ud af min erindring. [Sønderjyske Årbøger, 1923, side 167, bekræfter, at dette var tilfældet]. Mit virke var i så stor udstrækning rettet mod Midtlandet, at jeg vel i de sidste år lod Skærbæk noget $\mathrm{i}$ stikken. Jeg skulle undervise $\mathrm{i}$ Arnum, Toftlund, Rødding, Jels, Hjerting, Dover, Langetved o.s.v., dels i familier, dels i vandreskoler. « Löch slutter sit brev med at sende hjertelige hilsener til de tyske i Skærbæk, i særdeleshed familien Skau, samt ønsker Rahlf al lykke og fremgang i arbejdet. Hesteslagter Mads Skau var en ledende skikkelse inden for byens tyskhed. Han var desuden kaptajn i det frivillige brandværn og respekteret $\mathrm{i}$ vide kredse.

Löchs arbejdsplan for september 1922 er fremdraget af Arthur Lessow i en artikel i 1998. Den giver endnu mere detaljerede oplysninger. Det fremgår at Löch var i Skærbæk onsdag og lørdag. Om onsdagen hedder det: "Vandreskoleundervisning i Skærbæk $(22 \mathrm{~km}$ fra Toftlund, ud- og hjemvej 3 $\frac{1}{2}$ time) og bogudlevering der. Ved regnvejr med tog fra Toftlund kl. 10.50, hjemkomst Toftlund kl. 9 aften.« Vedrørende lørdag havde han ungdomsarbejde i Toftlund eller Arnum om formiddagen og weftermiddag 4-6 vandreskoleundervisning $i$ Skærbæk (og 31/2 time for ud- og hjemtur. Ved regnvejr med tog $5 \frac{1}{2}$ time). « Ugens øvrige dage underviste han i Toftlund og Jels. I en oversigt over vandreskolerne fra 1923 figurerer Skærbæk skole ikke. Den var altså ophørt en gang mellem sept. 1922 og udarbejdelsen af oversigten for 1923.

I forbindelse med indvielsen af den tyske skole i 1930 mindedes rektor Koopmann sit første besøg i Skærbæk 7-8 år tidligere. „Da sad vi også i Amtsbanegården og talte om tyskhedens fremtid på denne egn og drøftede indretningen af en vandreskole. Kun ganske få mennesker havde haft mod til at følge indbydelsen, og alle mente, at $\mathrm{i}$ Skærbæk havde det intet formål at gøre et forsøg i denne retning.« 


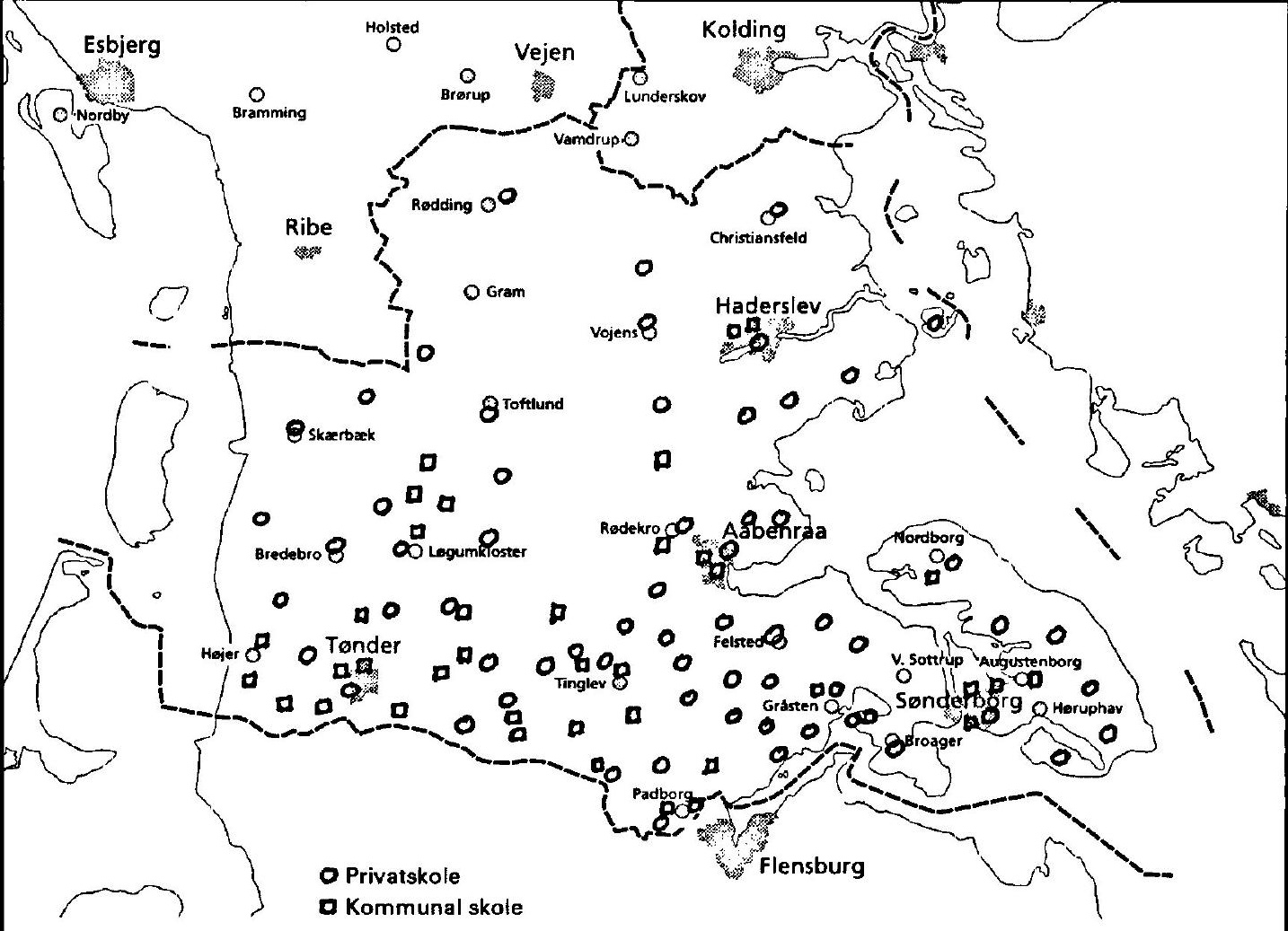

Kort over tyske skoler i Nordslesvig mellem 1920 og 1945. Tegning: H. E. Sørensen.

Det var den beskedne begyndelse på et tysk skolevæsen i Skærbæk. Skolen i Skaus dagligstue blev i øvrigt adopteret af byen Bredsted i Sydslesvig, som understøttede arbejdet, både moralsk og økonomisk.

\section{Den Tyske Skoleforening for Nordslesvig}

Genforeningen i 1920 betød naturligvis, at skolevæsenet i Sønderjylland skiftede fra tysk til dansk undervisningssprog og lovgivning. Derved blev også en meget stor del af lærerkorpset skiftet ud. De fleste tyske lærere blev afskediget og erstattet af danske lærere nordfra. Hvis forældrene onskede det, kunne de tidligere lærere dog få lov at blive og få ansættelse i den danske folkeskole, hvilket skete i mange tilfælde. Det var dog en betingelse, at de beherskede det danske sprog og i øvrigt gennemgik kurser i dansk skolelovgivning og undervisningspraksis.

I visse dele af Sønderjylland, specielt $i$ de fire købstæder samt $i$ landområderne nær grænsen, var en stor del af befolkningen tysk. 
Her var det et naturligt ønske og krav, at der også kunne finde undervisning sted på tysk.

For at fremme dette stiftedes Deutscher Schulverein für Nordschleswig (Den Tyske Skoleforening for Nordslesvig) på et møde i Flensborg den 4. maj 1920 - altså før den officielle genforening - med pastor Johannes Schmidt-Wodder, senere samme år tysk medlem af Folketinget, som formand og rektor Wilhelm Koopmann som sekretær og næstformand. Dertil kom et bestyrelsesmedlem fra hvert amt samt en repræsentant for den tysksprogede presse i Sønderjylland. Koopmann (født 1870), der havde været rektor for den højere pigeskole i Sønderborg og nu var førtidspensioneret, blev den daglige leder, og 1923 efterfulgte han Schmidt som formand. Han boede i Tinglev, som derfor blev organisationens hovedsæde.

Den danske lovgivning i forbindelse med Genforeningen gjorde det muligt at oprette tyske klasser i kommuneskolerne, hvis mindst 20 pct. af forældrene med minimum 10 børn krævede det. Det betød, at der i løbet af 1921 opstod 23 tyske kommuneskoler - eller skoleafdelinger - i Sønderjylland med i alt 2.556 elever. Der var tyske kommuneskoler $i$ alle fire købstæder med $i$ alt 1698 elever og derudover 4 skoler i Aabenraa amt, 2 i Sønderborg amt og 12 i Tønder amt med tyske klasser. De havde tilsammen 858 elever, eller et gennemsnit på 45 elever. Yderpunkterne var 87 i Løgumkloster og 13 i Solderup. I de følgende 15 år oprettedes flere tyske skoleafdelinger, de fleste $\mathrm{i}$ Tønder amt, hvor der i 1936 var 23 offentlige skoler med tysk undervisning.

Når der var så mange flere $\mathrm{i}$ Tønder amt end i de øvrige amter, skyldes det i første række, at der var en betydeligt større procentdel tyske på landet $i$ dette område end $i$ andre egne og derfor dobbelt så mange tyske elever $\mathrm{i}$ Tønder amt som i de øvrige, men også at amtsskolekonsulenten i Tønder, Nicolai Svendsen, gik varmt ind for, at mindretallets skolegang foregik inden for den offentlige kommuneskoles rammer. Det indebar bl.a., at den var underlagt de danske myndigheders tilsyn, også med hensyn til læreransættelser og undervisningsmidler.

Dette sidste betød, at der i tyske kredse opstod et onske om at oprette private skoler, hvilket man kunne gøre efter den danske lov om privatskoler af 1855 med senere tilføjelser, hvorefter enhver havde ret til at sætte sine børn i en privatskole eller selv at undervise dem; dog skulle undervisningen opfylde de samme betingelser, som gjaldt 
for den offentlige skole. Det stillede forældrene og dermed de tyske organisationer mere frit i forhold til myndighederne. Samtidig kunne skolen modtage et vist tilskud fra den danske stat, men det ville under alle omstændigheder være en tung økonomisk belastning at oprette en sådan skole, hvis man selv skulle stå for financieringen. Oprindelig opererede man med en forældrebetaling på $20 \mathrm{kr}$. pr. måned ( $240 \mathrm{kr}$. om året), hvilket med minimum ti elever skulle kunne dække en ugift lærers løn. Det var dog en meget høj egenbetaling, når en arbejdsmands ugeløn lå på 20-30 kr. Mange ønskede derfor forældrebetalingen nedsat til det halve, men selv dette ville gøre det vanskeligt for mindrebemidlede at sende deres born i disse skoler. I 1930'rne var betalingen i Skærbæk og Gånsager tyske privatskoler da også én krone pr. måned. Så lod det sig gøre.

Imidlertid lykkedes det ved en energisk indsats - ikke mindst fra Koopmanns side - at skaffe midler til oprettelse af en række privatskoler. Pengene kom i første række sydfra, hvor der fra den tyske regering via forskellige kanaler, som skulle skjule, hvor pengene reelt kom fra, ydedes betydelige summer. De administreredes af Oberschulrat dr. Eduard Edert, Slesvig, gennem dækorganisationen Deutsche Stiftung, der først og fremmest betalte lærernes løn, men også ydede betydelige tilskud til bygninger og inventar. I 1928 kunne Edert i dybeste fortrolighed meddele Koopmann, at hans organisation nu havde fået så store bevillinger, at den kunne påtage sig aflønningen af lærerne ved de tyske privatskoler i Sønderjylland i det omfang, den ikke dækkedes af det danske statstilskud.

En anden officiel tysk organisation, der ydede tilskud til tyske skoler i bl.a. Nordslesvig, var Verein für das Deutschtum im Auslande, V.D.A. (Foreningen for Tyskheden i Udlandet), hvis penge i stor udstrækning gik til inventar og undervisningsmidler. Dertil kom private organisationer som Schleswig-Holsteiner Bund, Wohlfahrts- und Schulverein für Nordschleswig (Velfærds- og skoleforeningen for Nordslesvig) og Verband der Vereine heimattreuer deutscher Nordschleswiger (Forbundet af Foreninger af Hjemstavnstro Tyske Nordslesvigere), den sidste med bankdirektør Jürgen Erichsen, Kiel, som formand. Han havde indtil afstemningstiden 1920 været amtsforstander (politimester) i Skærbæk, men var blevet udvist af Den Internationale Kommission (C.I.S.), der administrerede de to afstemningszoner i overgangstiden. I Slesvig-Holsten oprettedes på alle skoler afdelinger af den såkaldte Jugendspende (Ungdomsgave) med kon- 


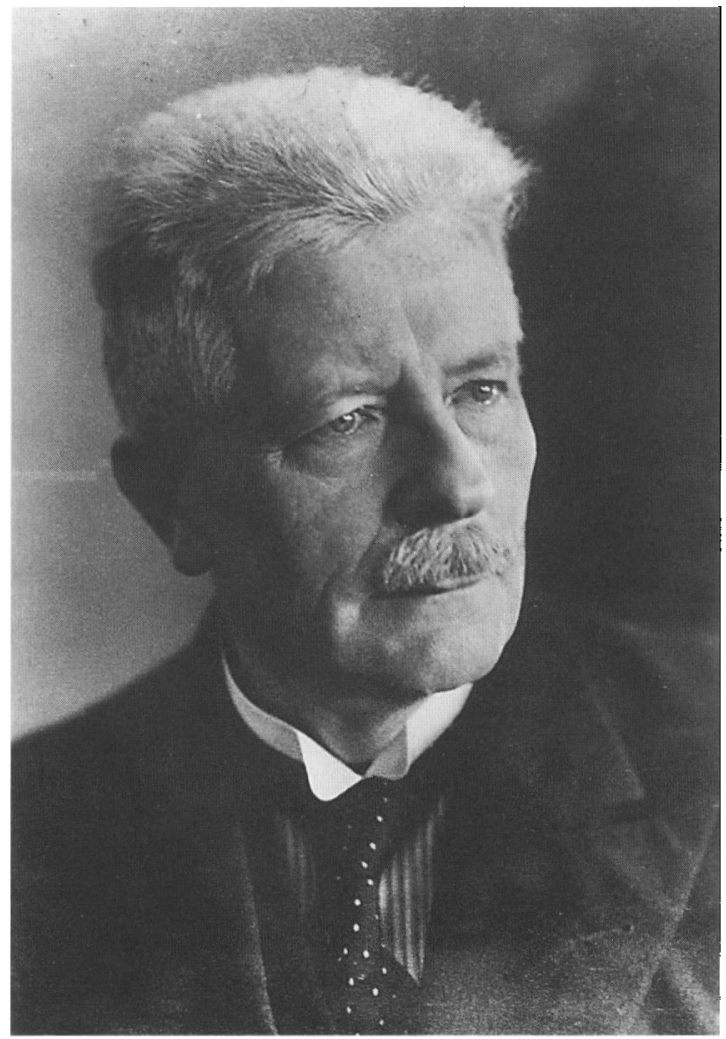

Rektor Wilhelm Koopmann (1870-1939), Tinglev. Som formand for Deutscher Schulverein für Nordschleswig udforte han et stort arbejde for opbygningen af de tyske privatskoler. Foto $i$ Institut for sonderjysk Lokalhistorie.

taktlærere, der hver måned holdt indsamling blandt eleverne, som gav efter vilje og formåen. De midler, der blev skaffet på denne måde, brugtes hovedsagelig til skolemateriel, udsmykning af undervisningslokaler o.l. Disse bidrag fremtrådte som solidaritets- og opmuntringsgaver fra de jævnaldrende kammerater syd for grænsen.

Mens V.D.A. og Deutsche Stiftung ydede en så betydelig økonomisk støtte til det tyske skolearbejde i Sønderjylland, at de i realiteten holdt det oppe, indskrænkede støtten fra de øvrige sig i de fleste tilfælde til smågaver, bøger, billeder o.l. Deres betydning var i første række en moralsk opbakning, der skulle vise, at fædrelandet stod bag de tyske skoler nord for grænsen.

Fra den danske stat modtog skolerne $47,25 \mathrm{kr}$. pr. skolepligtigt barn. Disse penge kunne dog først påregnes efter det første år, idet staten forbeholdt sig ret til at se, om skolen i det hele taget fungerede, og 
om den efterlevede de krav, der måtte stilles, inden der udbetaltes støtte.

Alle disse penge - incl. statstilskuddet, som skolen skulle lade gå videre - administreredes af Schulverein, d.v.s. Koopmann, som stod for udbetaling af lærerlønninger, udgifter til skolemateriel og stort set alle andre udgifter. Den lokale skoleforening, altså forældrekredsen, havde i princippet ansvaret for bygningens vedligeholdelse samt udgifter til varme og el m.v. Dens indtægter var dog ret små, idet de bestod af bl.a. lærerens husleje, medlemmernes kontingent og evt. overskud fra arrangementer. Som regel måtte Koopmann træde til, når større beløb var nødvendige.

I 1921 oprettedes 6 privatskoler, og inden 1930 var man oppe på 22. I de næste fem år fulgte 32 skoler, heraf over halvdelen i 1933. 1935-38 oprettedes ingen skoler, i 1939 en enkelt, og 1940-42 fulgte yderligere 10 skoler. I alt blev der mellem Genforeningen og 1945 oprettet 100 tyske skoler i Sønderjylland, heraf 65 privatskoler. Enkelte blev dog nedlagt eller slået sammen med andre. Det højeste tal nåedes under besættelsen (1941-44) med 90 skoler samtidig (59 private og 31 offentlige). De to sidste kom så sent som 1942 i BallumRanderup og Kegnæs. Også i købstæderne oprettedes privatskoler ved siden af de tyske kommuneskoler. De fleste landskoler var ret små med 20-30 elever og en enkelt lærer. Den mindste var skolen på Årø med under ti børn. Kun fire privatskoler uden for købstæderne havde over 40 elever.

\section{Skolen i Skærbæk oprettes}

Kort efter nytår 1930 fik Koopmann en henvendelse fra mekaniker Hermann Kohl i Skærbæk, som på nogle tysksindede forældres vegne spurgte om muligheden for at få oprettet en tysk skole i byen.

Koopmann reagerede omgående, og den 22. januar om aftenen holdtes et møde $\mathrm{i}$ Kohls hjem. Her deltog ti fædre, der alle havde skolepligtige børn eller børn, som stod foran at skulle begynde $i$ skolen. Kohl fortalte, at man allerede længe i lukkede kredse havde talt om muligheden af at oprette en tysk skoleklasse, og da stemningen nu syntes gunstig, havde han henvendt sig til de tyske familier, han kendte, og fået forældrene til 20-21 børn til at skrive under på, at de ønskede deres børn undervist på tysk. Spørgsmålet var, hvorledes man skulle gribe sagen an. Alle forældrene var arbejdere 


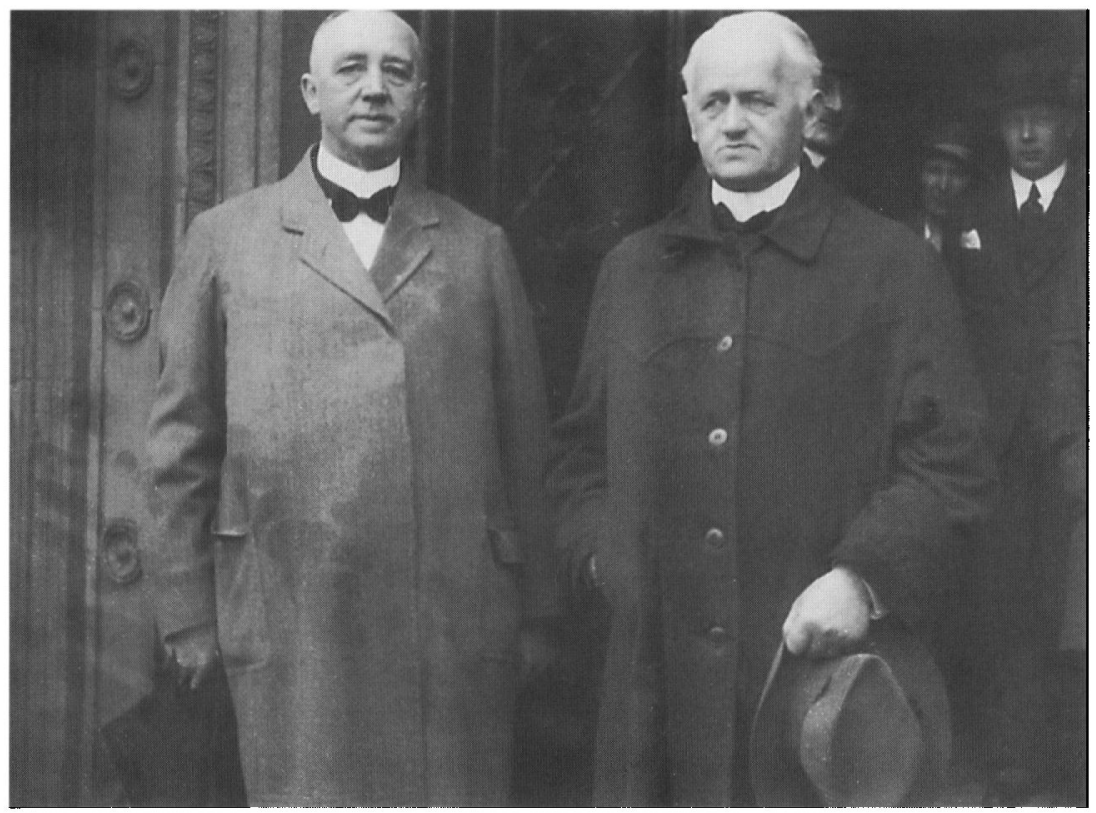

To mænd, som betød meget for opbygningen af de tyske skoler. Pastor Johannes Schmidt (t.h.) var mindretallets repræsentant $i$ Folketinget 1920-39 og formand for den tyske skoleforening 1920-23. Bankdirektør Jürgen Erichsen, Kiel, (t.v.) var frem til 1920 amtsforstander $i$ Skærbæk. Som formand for Verband der Vereine heimattreuer deutscher Nordschleswiger skaffede han betydelige midler til skolernes etablering og drift. Foto i Institut for sønderjysk Lokalhistorie.

og småhåndværkere, så deres økonomiske formåen var meget ringe.

Koopmann oplyste, at det ville kræve henvendelse fra 20 pct. af forældrene i sognet at få oprettet en kommunal tysk skoleafdeling, hvilket måtte anses for udelukket, eller mindst 24 børn. Dette sidste kunne vel opnås med tiden, men i øjeblikket var de ikke for hånden, og "modstanderne« (danskerne) ville bruge alle midler for at skræmme de usikre fra at melde deres børn til en sådan klasse. Det var derfor nødvendigt selv at oprette en skole. Men først skulle man danne en privatskoleforening og i gang med et energisk hvervearbejde for at skaffe eleverne, ligesom der skulle findes et egnet lokale og ansættes en lærer.

Det har sikkert lydt voldsomt for de ret fattige forældre, men Koopmann beroligede dem med, at lærerens løn tog Schulverein sig af, mens lokalforeningen måtte sørge for resten, idet man dog i begyn- 
delsen kunne påregne tilskud til leje af skolestuen. Det var så heldigt, at bankdirektør Erichsen havde en ganske særlig interesse for oprettelse af en tysk skole i sin tidligere hjemby. På vegne af Verband der Vereine heimattreuer deutscher Nordschleswiger havde han lovet at støtte et sådant foretagende.

Koopmann regnede med, at det $\mathrm{i}$ løbet af 1-2 år ville blive nødvendigt at bygge eget skolehus. Man ville derved ikke alene få en skolestue og et rum til ungdommen, men også et forsamlingslokale, idet de to rum kunne slås sammen til ét. Det ville i høj grad sætte skub i den lokale tyskhed, hvilket igen ville øge muligheden for tilskud.

Efter en lang diskussion blev det besluttet at vove forsøget. Der skulle under hånden agiteres kraftigt blandt byens tyske familier, man skulle finde et lokale, og om ca. 14 dage skulle man igen mødes og officielt stifte foreningen. Kohl og Koopmann ville holde sig i kontakt.

Koopmann sendte referat af mødet til Edert og Erichsen, som straks støttede tanken og lovede økonomisk støtte. Knap tre uger senere $(19 / 2)$ kunne Koopmann oplyse, at antallet af tilmeldte børn var "stigende«. Men tyskerne i Skærbæk var under et arbejdsmæssigt tryk og følte sig meget afhængige. "Men når skolen først er der, vil de skare sig om den. « Der var 80 tyske stemmer i Skærbæk ved sidste valg [1929: 66 tyske stemmer], men da de fleste tyske hørte til underklassen, holdt de sig hjemme eller stemte socialdemokratisk »for dog at vise en vis opposition ". Men en tysk skole ville bringe "Schwung" i det tyske liv. For tiden var der end ikke tysk gudstjeneste i Skærbæk. Når den tyske pastor Horstmann prædikede, var kirken ganske vist fuld, men han prædikede på dansk, skrev Koopmann beklagende. Horstmann havde før Genforeningen været præst i Skærbæk, men boede nu i Haderslev, hvorfra han som en slags "vandrepræst « betjente de spredte tyske menigheder i de vestlige sogne. Når man fik "eget hjem", ville man også kunne afholde tysk gudstjeneste, og "tyskhedens stilling ville $i$ det hele taget blive en anden«. Derfor var en privatskole at foretrække for en kommunal skoleafdeling, da man så også selv kunne ansætte læreren og være sikker på at få en, der »inderligt hører til hos os«. - Hvis der kom en dygtig mand, "vil skolen, hvad jeg håber, blive et samlingspunkt for tyskheden i nordvest-hjørnet«. En vedlagt liste viste, at der nu var tilmeldt elleve hjem med 24 skolepligtige og 13 ikke-skolepligtige børn.

Samme dag, som han havde skrevet dette, var Koopmann i Skærbæk, hvor han beså det lejede lokale, som han fandt velegnet, og om 
aftenen afholdtes det stiftende møde i Deutscher Privatschulverein Scherrebek på Amtsbanegårdens restaurant. Den bestyredes af Rudolf Stehr, der ligesom Skau hørte til de toneangivende tyske $\mathrm{i}$ byen. 191921 var han som den eneste tysker indvalgt $i$ kommunerådet.

Alle 11 hjem var mødt, og alle erklærede sig rede til at gå med, på nær den lokale skorstensfejer, som oplyste, at han gerne sendte sine børn i skolen og glad betalte skolepenge, men som tysk statsborger turde han ikke gå ind $\mathrm{i}$ foreningen, da han var bange for at risikere udvisning. Der blev nedsat et udvalg til at udarbejde statutter. Her var både Kohl og Skau medlem.

Schulverein betalte lærerens lon, oplyste Koopmann, ligesom den ville give $250 \mathrm{kr}$. til en mindre ombygning af skolestuen og indretning af toiletter samt bidrage med $40 \mathrm{kr}$. pr. måned til leje af lokalet, foreløbig $\mathrm{i}$ et år. Skolen skulle åbne 1. april eller efter påske. Referatet underskreves af samtlige tilstedeværende undtagen skorstensfejeren.

Fire dage senere skrev Kohl til Koopmann, at man i stedet for det lokale, der havde været på tale, havde lejet et andet, som var både større og bedre beliggende, og hvor der var et par værelser til læreren i tilknytning til skolestuen. Det lå i Skyttegården, et tidligere værtshus i byens nordlige udkant, hvor Kohl i øvrigt også selv boede. Man skulle give $50 \mathrm{kr}$. for skolestuen og $20 \mathrm{kr}$. for lejligheden om måneden. Koopmann måtte indrømme, at dette lokale var bedre end det første, men mente ikke, man burde leje de to værelser, da det måtte forventes, at der kom en gift lærer til Skærbæk. Det må forstås sådan, at så var logiet ikke tilstrækkeligt. Han havde åbenbart allerede udset sig manden, for få dage senere (28/ 2) meddelte han Kohl, at Andreas Rahlf, der var gift og havde to små børn, skulle til Skærbæk. Han var født 16/10-1903 i Ascheffel i Hütten sogn mellem Slesvig og Eckernførde og uddannet på seminariet $\mathrm{i}$ Rendsborg. Hidtil havde han haft stilling på den tyske skole i Sdr. Vilstrup og var p.t. på Askov Højskole for at forbedre sit dansk. Han ville henvende sig til Kohl eller Skau, som havde fundet en lejlighed til ham ca. ti minutters gang fra skolen. Det glædede Koopmann, "ellers havde Skærbæk måttet nøjes med en lærerinde«. Hun kunne bo $i$ et værelse!

Hidtil havde man holdt planerne hemmeligt, men nu var det tid til at offentliggøre dem. Det skete ved en ganske kort notits i Nordschleswigsche Zeitung 5/3, som gengaves i Flensborg Avis dagen efter med en syrlig kommentar: "Man skulle ikke synes, at der foreligger 
trang til en tysk skole her i byen, men det er formodentlig heller ikke forældrene selv til de børn, der skal besøge den, som har fostret tanken.« Skærbæk Avis sukkede: »Det kan der vel ikke være noget at sige til, det er vel kun selvbestemmelsesretten, der gør sig gældende." Nogle dage senere skrev Nordischer Kurier i Itzehoe, at skolen skyldtes stærk tysk fremgang, hvilket fik Heimdal (Aabenraa) til at kommentere: »Den »stærke fremgang« af tyskheden i Skærbæk har særligt vist sig i tilbagegang i de tyske stemmer, og endvidere $i$, at den tyske frimenighedspræst har gjort alvor af sin tidligere omtalte plan om at holde de tyske gudstjenester - på dansk! «

Kohl regnede med at åbne 1 . maj, mens Koopmann mente, man burde stile imod at åbne 4 . eller 8 . april, lige før påske, så var skolen i gang, og man kunne starte undervisningen efter påskeferien. Hvis man ikke fik begyndt før $1 / 5$, ville Rahlf ikke få løn i april, da "man jo ikke kan lønne en lærer i en måned, hvor han ikke bestiller noget så er lønnen jo direkte kastet bort(!) - Det har efter min opfattelse ingen mening at tøve, i stedet vanskeliggør det sagen. Derfor må De arbejde hurtigt og energisk, så jeg kan sende inventaret 2. el. 3. april«. Skrevet $15 / 3$.

Det lykkedes dog ikke. Skolens åbning blev fastsat til 2. maj. Koopmann rasede. Der ville ikke blive betalt for april på grund af forsinkelsen, "da der kun kan gives tilskud til leje for den tid, skolen eksisterer«. Rahlf havde sagt til ham, at der var tilmeldt 34 elever. Det betvivlede han og skrev til Erichsen, at det nok var ret overdrevet. Hvad det også var.

Indvielsen af skolestuen fandt sted om eftermiddagen den 2. maj 1930. Erichsen og pastor Horstmann deltog. Næste dag berettede Koopmann herom i breve til Schmidt-Wodder og repræsentanter for de foreninger og udvalg syd for grænsen, som havde støttet oprettelsen. Der var »ikke mindre end « 27 børn i skolen "allerede fra første dag ", skrev han begejstret og var glædeligt forundret over, at så mange forældre havde indfundet sig $\mathrm{i}$ »det festligt smykkede skolelokale«. Da de fleste fædre var på arbejde, kunne de ikke være med om eftermiddagen; derfor afholdtes et kaffebord på Amtsbanegården samme aften. Stehr ventede ikke ret mange og havde kun dækket op i det ene af restaurationens rum, men "jeg tror, at alle var lige så glædeligt overraskede som jeg, da begge rum blev fyldt «, skrev Koopmann og sluttede: "Der synes dog at være ganske meget tysk liv i Skærbæk.« 


\section{Eget skolehus}

Samtidig var man i gang med at finde en plads til opførelse af skolen og besluttede sig for en grund på 4200 kv.m. bag Skyttegården ud mod Ribevej. Koopmann mente dog, at den var lovlig stor. Ved et møde med foreningens bestyrelse 21/6 forelagde han to muligheder for skolens udformning. Enten en bygning med lærerlejlighed på loftet som i Rødding eller $i$ to etager som i Sommersted, $i$ begge tilfælde med skolestue og ungdomslokale nedenunder. Man ville kunne påregne en bygningshjælp på $17.000 \mathrm{kr}$. Skau mente, at det måske var en idé at se tiden lidt an, så man var sikker på skolens beståen, mens andre havde den opfattelse, at egen bygning netop kunne styrke skolen.

På en generalforsamling den $6 / 6$ vedtoges det enstemmigt at indlede byggeriet. Grunden erhvervedes for 3.400 kr. Koopmann blev vred og bebrejdede dem, at de havde købt det dyre areal "uden at have en øre i hånden". Han havde sagt, at han måske kunne formidle en byggehjælp, men ikke lovet noget, og bestyrelsen havde ikke på mødet med ham været stemt for et byggeri her og nu.

Kohl faldt helt ned. De havde haft det indtryk, at pengene var til rådighed, skrev han. Derfor var de nu i en slem forlegenhed, da handelen ikke kunne gå tilbage. Han måtte på det indstændigste bede Koopmann om dog at skaffe pengene. Også Rahlf skrev til Koopmann. Bestyrelsen troede, at købet ville have vakt stor glæde, og kunne slet ikke forestille sig, at de penge, som Koopmann havde lovet dem, ikke var sikre. Ja, Rahlf måtte tilstå, at han havde fået det samme indtryk. Men han havde dog sagt til bestyrelsen, at den havde handlet forkert ved ikke straks at meddele Koopmann, at man agtede at bygge allerede $\mathrm{i}$ år, da han på mødet hos Stehr havde fået en anden opfattelse. Men hvis byggearbejdet ikke blev til noget, ville det give et »tilbageslag, som vil være svært at forvinde«. Han håbede, at rektoren ikke ville »lade skærbækkerne i stikken«.

Koopmann havde opnået, hvad han ville. Skærbæk-bestyrelsen havde fået en lektion om, hvem der bestemte. Så efter at den havde svedt i nogle dage, meddelte han i et betydeligt mildere toneleje, at pengene var fundet. Grunden var blot alt for stor. Halvdelen havde været nok. Han gik selvfølgelig ind for byggeriet og lovede 15-16.500 rigsmark (14-15.000 kr.) i støtte. Samtidig advarede han kraftigt bestyrelsen om aldrig mere at gå ind på forpligtelser, den ikke kunne ind- 
fri. "Sådanne summer ligger sandelig ikke på gaden i dag«. Koopmann håbede dog at kunne skaffe en støtte, der svarede til den tidligere lovede. Men den yderste sparsommelighed måtte kræves. Og han forlangte, at to kendte tyske gårdmænd fra Gasse, Wilhelm Fisker og Peter Hjort, senere amtsrådsmedlem for Slesvigsk Parti, skulle indtræde i byggeudvalget. De var ikke var med i skolebestyrelsen, da de var ugifte og ikke havde børn.

Arkitekt Bock, Haderslev, udarbejdede skitser til en toetagers skolebygning med klasseværelse og ungdomslokale med en skydedør imellem, samt forgang og kaffekøkken nedenunder og lærerlejlighed ovenpå. Bag huset lå en toiletbygning. Den totale udgift ville blive $27.500 \mathrm{kr}$. Heraf udgjorde grunden 3.400 , byggeriet 20.450 , honorar til arkitekten 600 . Bygmester N. Jürgensen, Haderslev, skulle stå for opførelsen.

Der var givet tilsagn om $15.000 \mathrm{kr}$. i direkte støtte sydfra, hvorfor Skærbæk-foreningen hæftede for $12.500 \mathrm{kr}$., som den måtte ud at låne. Fra Kreditforeningen kunne skaffes 10.000, så der var en manko på $2.500 \mathrm{kr}$. Koopmann rådede Kohl til at søge Nordschleswigsche Gemeinde (den tyske frikirke), som dog måtte beklage. Der var ingen penge. Men 4/9 kunne Koopmann oplyse, at Jugendspende havde lovet at hæve sit tilskud med 750 rigsmark under forudsætning af, at de andre bidragydere også øgede deres bidrag. Han ville derfor endnu en gang henvende sig til Erichsen.

Denne svarede $9 / 9$, at hvis skærbækkerne optog et yderligere kreditforeningslån til dækning af de manglende 2.500 kr., ville de hjemstavstro tyske nordslesvigere betale renterne. Koopmann svarede, at på grund af tilsagnet om de 750 mark fra Jugendspende var det kun nødvendigt at låne yderligere $1.500 \mathrm{kr}$, som han foreslog, at de hjemstavnstro betalte renter og afdrag af. Han tilføjede: "Skærbæk må være meget sparsommelige. Der må ikke stilles flere penge til rådighed end nødvendigt.« Dette gik Erichsen ind på. Hans forening ville betale renterne foreløbig i fem år plus $100 \mathrm{kr}$. om året til afdrag. Nogle dage senere lovede også dr. Edert yderligere 750 mark. Økonomien nåede sammen.

Omkring 1. oktober begyndte byggeriet, og 28/11 holdtes rejsegilde. Der kom adskillige vimpler, og over 100 mennesker mødte op.

I løbet af vinteren blev skolen færdig, i april bestiltes skoleborde, stole o.s.v.. Lærer Rahlf skrev til Koopmann, at man snart var klar til at flytte fra den gamle skolestue og ville kunne tage den nye skole i brug 


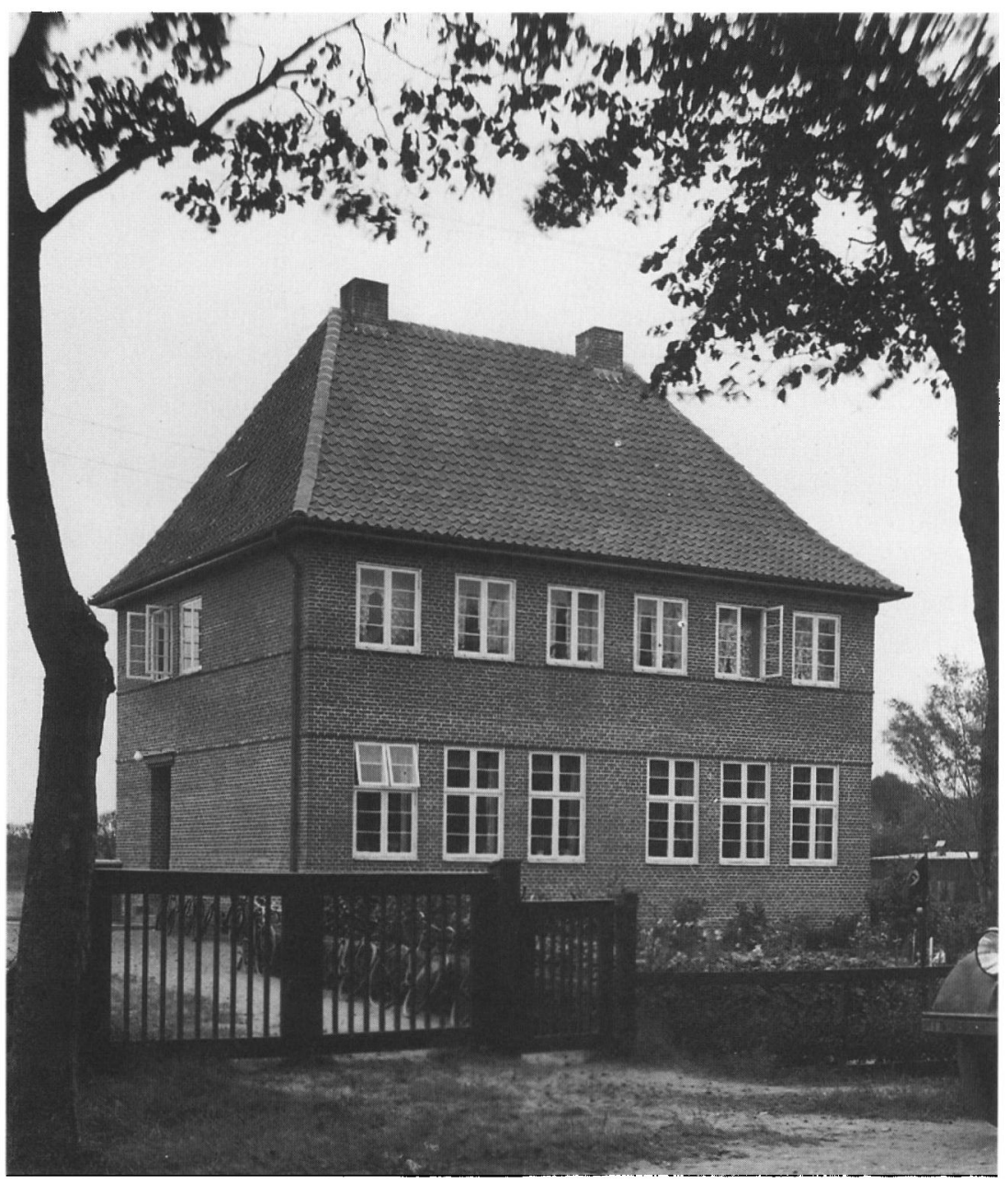

Den tyske skole $i$ Skærbæk set fra Ribevej midt i 1930'erne. Foto i Adeline Hauschildts album. Skærbæk Museums billedsamling.

1. maj. Da Rahlf ikke behørigt havde meddelt dette, fik han 7. maj en over næsen af Koopmann: »En formodning om, at man kan rykke ind, er ikke det samme som en meddelelse om den faktiske kendsgerning «. Læreren indberettede derefter tjenstligt, at man havde haft den sidste skoledag i det gamle lokale 30/4, hvorefter eleverne fik fri lørdag d. $2 / 5$ på grund af omflytningen, således at første regulære skoledag i den nye bygning havde været mandag den 4 . maj 1931. 
Koopmann var der med et piskesmeld: "Jeg er forbavset over at måtte fastslå, at De har ladet undervisningen falde bort lørdag den 2 . maj. De ved dog ganske nøje, at De i hvert enkelt tilfælde har at give mig meddelelse herom. Jeg håber, at De ikke igen vil lade en sådan efterladenhed forekomme."

\section{Indvielsen}

Indvielsen fandt sted den 21. juni 1931 om eftermiddagen. Skolestuen og ungdomslokalet var slået sammen for at skaffe plads til elever og forældre og de mange gæster fra både nord og syd for grænsen, der stod som sild i en tonde. I alt var 0.120 mennesker stuvet sammen $i$ lokalet.

Kohl bød velkommen og mindedes vandreskolen, hvorefter man sang "Nun danket alle Gott". Pastor Horstmann ledede en kort andagt og efter endnu en salme holdt Koopmann indvielsestalen.

Det var et ejendommeligt tilfælde, begyndte han, at man næsten samtidig kunne indvi nye tyske skoler $i$ alle hjørner af det afståede område: Lydersholm i sydvest, Sommersted i nordøst, Skovby på Als og altså Skærbæk i nordvest. Det var »et urokkeligt bevis på, at tysk kraft, tysk livsvilje i Nordslesvig endnu er levende“. Og det var en uimodsigelig gendrivelse af de ledende danskes påstand om, at tyskheden i Nordslesvig ville smelte bort som is i solen. Tyskheden lever, fortsatte han og henviste til, at der netop få dage forinden var startet en vandreskole $\mathrm{i}$ Gånsager med 15 elever.

Det skulle være et tysk hus, et plejested for tyske kulturelle udfoldelser, men først og fremmest en skole.

Trods hårde tider også syd for grænsen var det lykkedes af rejse de nødvendige midler. Vi skal ikke sige som en af Fritz Reuters romanpersoner: "Wat shall eener dabi dahn? (Hvad skal én gøre ved det?) - nej, man skal bide tænderne sammen også i svære tider, sætte sin vilje igennem og finde modet til trods al nod og modstand at kæmpe videre.

Den tyske ungdom skulle opdrages til ikke som ambolten passivt at modtage slag, men som hammeren at slå slag for deres folkefællers skæbne. (I sit referat af talen mindedes Heimdal, at det var omtrent de samme ord, Skærbækpræsten Chr. Johs. Jacobsen havde brugt ved afsløringen af det slesvigholstenske mindesmærke på Brøns kirkegård 1899). Koopmann citerede derefter et vers af Grundtvig, der taler 
om tysk som "edder og forgift" og fremhævede i stedet den schweiziske digter Gottfried Kellers ord "Achte jedermanns Vaterland, aber das deinige liebe« (Agt enhvers fædreland, men elsk dit eget). Det var et langt højere standpunkt, sagde han. Den danske holdning som udtrykt af Grundtvig er et tegn på svaghed. Når man føler virkningen af tysk kultur, så bekæmper man den. "Vi vil i stedet højagte den tyske kultur og tage det værdifulde fra andre. Vi tror ikke på, at tysk kultur lider under, at vi også finder noget værdifuldt i den danske kultur.«

Han vendte sig derpå til Rahlf og gav ham et par formanende ord: "De véd, at vi kun kan bruge mennesker med stålsat energi og stor arbejdsglæde, lærere, der glæder sig, når nye opgaver vokser op omkring dem, for hvem arbejdet ikke er en byrde, men en lyst. De kender den stillede opgave - véd, hvad vi venter af Dem." Efter flere taler takkede lærer Rahlf for de gode onsker og forsikrede, at han ville sætte al sin kraft ind på at vise de ham betroede børn vejen til kærlighed til Gud og mennesker og opdrage dem til tro tyskere. Festen i skolestuen sluttede med Tysklandssangen "Deutschland, Deutschland über alles«.

Efter en rundgang i huset gik man til kaffebord på Nørbys Hotel, hvor salen var fyldt. Her talte Schmidt-Wodder, som mindedes sin tid som præst i Vodder. Dengang herskede den tyske skole i Skærbæk. $\mathrm{Nu}$ var den genopstået ved forældres og børns kærlighed. Direktøren for det slesvigholstenske landbrugskammer, dr. Thyssen, Kiel, der var født i Skærbæk, sagde, at i 1920 havde de tyske i Skærbæk følt sig som soldater på tilbagetog. Nu var de på fremmarch igen. I denne egn er tyskheden meget spredt, men så meget mere må ryggen rankes. Erichsen inviterede eleverne på et otte dages ophold i Kiel, og pastor Horstmann sluttede med andagt.

Skolen var behørigt indviet.

\section{Skolen i Gånsager}

Ved en tysk aften (Gemeindeabend) i begyndelsen af januar 1931 spurgte nogle forældre fra den lille landsby Gånsager i Vodder sogn nordøst for Skærbæk, om ikke det var muligt at få deres børn undervist på tysk. Lærer Rahlf lovede at lade det gå videre til Koopmann. Det drejede sig om ca. ti børn, som på grund af den store afstand - 12-15 kilometer - næppe ville kunne sendes til skolen i 
Skærbæk, da der ikke var nogen jernbaneforbindelse. Det var dog hans indtryk, at folkene fra Gånsager foreløbig ville være tilfreds med en vandreskole. Men heller ikke det ville være så let, fortsatte Rahlf, for på grund af eftermiddagsundervisning kunne han ikke påtage sig opgaven.

Det er tydeligt, at Rahlf ikke var varm på det ekstra arbejde. Det ville betyde, at han en eller to eftermiddage om ugen - efter at have afsluttet undervisningen i Skærbæk - skulle cykle den lange tur ad elendige grus- og sandveje til Gånsager for efter yderligere to-tre timers undervisning at køre hjem igen, uanset vejret. Det så meget mere, som han næppe ville få ekstra honorar for dette. Efter hjemkomsten var der så aftenskoleundervisning, møder m.v. Og netop i disse dage ventede ægteparret Rahlf deres tredje barn, som fødtes 15 . februar. Når han var færdig i skolen, ville han meget naturligt gerne være sammen med familien.

Sådan så rektoren ikke på sagen. Han lagde pres på Rahlf, som snoede sig for at slippe, og 11/6 eksploderede Koopmann. Rahlf havde til hans største forundring endnu ikke afsluttet sine overvejelser, skrev han. I det mindste havde han ikke erfaret noget herom. Men nu var sagen ordnet, idet lærer Ludwig Claussen fra den tyske skole i Toftlund havde påtaget sig opgaven. For ham var vejen ikke for lang, tilføjede rektoren spidst og lod derefter hammeren falde, idet han erindrede Rahlf om en beslutning, der var truffet i Schulvereins bestyrelse på et møde i Aabenraa:

"Forudsætningen for en ansættelse $i$ det tyske mindretals tjeneste er imidlertid, at det drejer sig om personligheder, der har faste og dybe rødder i den tyske kultur, som stedse åbent har bekendt sig som tyske, og som er beredt til at påtage sig yderligere arbejde $\mathrm{i}$ tyskhedens interesse uden ekstra honorering. For ansøgere, der ønsker ansættelse af ydre grunde, er der ingen plads i vore rækker.«

Den skjulte trussel kunne ikke undgå Rahlfs opmærksomhed.

Og han har været fuldt ud klar over, hvad der lå bag, når Koopmann ved indvielsen af skolebygningen i Skærbæk fjorten dage senere glædede sig over, at vandreskolen i Gånsager var kommet i gang, samtidig med at han indskærpede Rahlf hans embedspligter.

I et brev til Schmidt-Wodder (4/11) skrev Koopmann, at Rahlf var 


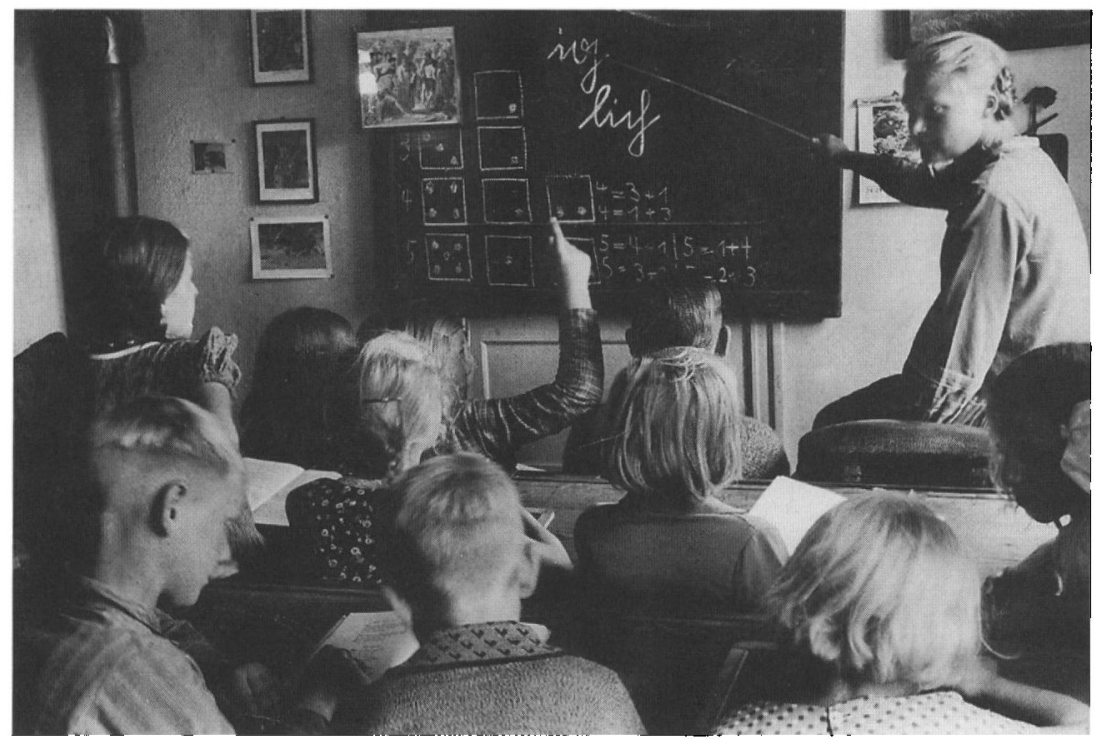

Lydia Wohlenberg og eleverne $i$ det forste klassevarelse $i$ Chr.P. Jorgensens sovevarelse $i$ Gånsager kort far overflytningen til den nye skole 1933. Foto: Erich Andres. Skærbæk Museums billedsamling.

lovlig "bequem " (magelig), og han havde kun overdraget arbejdet til Claussen, for hvem det var endnu mere ubekvemt, men som gerne havde påtaget sig det, fordi Rahlf havde været så uvillig. Han kunne have tvunget ham til at tage til Gånsager, men "sådanne arbejder ved siden af har kun fremgang, hvis de ydes med glæde«. En lærer, der ikke tager sig af sin vandreskole, kan bevirke, at børnene helt udebliver, sluttede han.

Claussen fortsatte med vandreskolen det næste halve års tid, og 3/2-1932 kom Koopmann til Gånsager for at drøfte stiftelsen af en lokal skoleforening med forældrene, der alle var små gårdmænd og landarbejdere. Et års tid senere kom en enkelt større gårdmand med. Fra 5-6 hjem var der tilmeldt 14 børn. I flere af hjemmene var der over 10 børn, så der var noget at bygge fremtiden på.

Man mødtes hos Christian Peter Jørgensen, en arbejdsmand, som kort forinden havde bygget hus med lån fra den tyske kreditforening Kreditanstalt Vogelgesang i Haderslev. Jørgensens søn fortæller, at faderen fik dette lån under forudsætning af, at et rum i huset skulle bruges som tysk skolestue. Det er der dog intet belæg for i kilderne, idet en sådan aftale ikke omtales noget steds. Tværtimod måtte huset 
gennemgå en mindre ombygning, før rummet kunne bruges. Det var familiens soveværelse, som var 4,05 meter på den ene led og 3,20 meter på den anden, altså o. 13 kv.m. Jørgensen erklærede sig villig til at rykke væggen en halv meter, så skolestuen blev et par kv.m. større og den private stue det mindre. Koopmann mente stadig, det var for trangt, og dr. Edert sagde senere, at det var den mindste skolestue, han nogen sinde havde set. Jørgensen skulle have $100 \mathrm{kr}$. i årlig husleje incl. varme og rengøring. Ombygningen ville løbe op i ca. 500 kr., og så »nærmer rummet sig end ikke det, vi har brug for «, noterede Koopmann. Den kommende lærerinde kunne leje to sammenhængende værelser hos gårdejer Heinrich Grundt, en af initiativtagerne.

Efter besigtigelsen mødtes man hos Grundt. Der var ikke fuld klarhed over, hvor stort børnetallet ville blive, da en husmand i Frifelt med tre skolepligtige børn var interesseret, men holdt sig tilbage på grund af afstanden (ca. $5 \mathrm{~km}$ ). Koopmann var meget usikker og skrev til pastor Horstmann, at man aldrig havde forsøgt at stifte en skole på et så usikkert grundlag.

Lærer Claussen skrev til ham, at man snart måtte tage en beslutning, ellers faldt det hele fra hinanden. Forældrene »er som alle einfache Leute som børn«. De gav op, når de mødte modstand. Det var naturligvis et stort ansvar at grundlægge en skole, men ansvaret ville måske hvile tungere på dem, hvis man lod være.

Koopmann spurgte den erfarne lærerinde Lydia Wohlenberg i Sommersted, om hun ville påtage sig opgaven, og da hun sagde ja, svarede han hende bemærkelsesværdigt høfligt og respektfuldt, især når man tager den tone i betragtning, han ellers anvendte over for sine lærere. Han glædede sig meget over, at hun ville overtage stillingen og tilføjede, at han havde været meget usikker over for denne skolegrundlæggelse, da det netop i dette tilfælde i så høj grad afhang af lærerinden. "Kun en lærerinde, som af ideale grunde vil påtage sig denne svære, men dog så skønne opgave, kan yde, hvad man der forventer af Dem.« Samtidig meddelte han Grundt, at han nu havde besluttet sig.

Lydia Wohlenberg (f. 3/11-1899) var præstedatter fra Schobüll nord for Husum og havde gået på Erlangen seminarium i Bayern 1916-17 og senere på Oberlyzeum i Altona. Hun havde som nævnt allerede i genforeningstiden påtaget sig en opgave i det tyske skolevæsen som vandrelærer $i$ den østlige del af Haderslev amt. 1926-28 var hun ved privatskolen i Haderslev og fra 1928 i Sommersted. Hun var således en erfaren og særdeles velanskrevet lærer. 
Skolen åbnede 19. april, og to dage senere fandt indvielsen sted. Claussen bød kort velkommen, og efter en salme talte Koopmann. Netop i svære økonomiske tider var det vigtigt at give børnene en så god oplæring som muligt. Derfor ønskede forældrene denne tyske skole, og derfor har vi hjulpet med til at opfylde dette onske, sagde han.

Fem dage senere blev Deutscher Privatschulverein Gonsagger stiftet med gårdejer Nis Petersen som formand.

For at skaffe støtte, skrev Koopmann 2/4 til Husmoderforeningen (Frauenverein) i Kiel og spurgte, om den ville overtage et fadderskab for skolen. Det var i pastor Schmidts gamle sogn, påpegede han, og det drejede sig om tyske nybyggere på heden, der »taler plattysk til daglig, men som er tvunget til at sende deres børn i den danske folkeskole, hvorved børnene bliver danske«. Der var 14-15 børn i skolen og lige så mange små søskende, så »vi kæmper om 30 tyske menneskers fremtid «, sluttede han patetisk.

Umiddelbart før sommerferien fortalte Wohlenberg $i$ et begejstret brev til Koopmann om skolen: Man havde i den varme sommer flyttet undervisningen ud i en nærliggende sandgrav, som børnene havde udsmykket. »Til min overraskelse havde de store i går lavet en sorthvid-rød fane, der endnu her til morgen stod derude. Jeg tog den ind, da sandgraven tilhører den danske sognerådsformand. Men jeg forbavses hele tiden over den tyske bevidsthed i denne lille skare, der $\mathrm{i}$ årevis har gået $\mathrm{i}$ den danske skole og næppe har hørt et tysk ord hjemme. De vil ikke mere tegne et dansk flag og kun tale tysk i frikvarteret«. Samtidig var hun begyndt at samle de unge i skolen to aftener om ugen. "Det har De forhåbentlig ikke noget imod?«

- Om han havde. Han har været henrykt!

Sommerferien tilbragte den energiske dame hos en familie i Gentofte for at forbedre sit dansk og vel også for at lære København at kende.

\section{Eget skolehus}

Efter nytår 1933 gik man i gang med forberedelserne til at bygge en skole, da forholdene i Jørgensens soveværelse var alt for trange. Wohlenberg skildrer malende, hvorledes de store knægte ved aftenskolen sad med de lange ben ud af døren til forgangen for overhovedet at kunne være derinde! 
Arkitekt M. Krogh-Haust tegnede et udkast efter samme læst som skolen i Skærbæk og mange andre små tyske skoler. Skolestue, ungdomslokale, forgang og kaffekøkken nedenunder og på loftet lejlighed til lærerinden med to stuer, soveværelse, gæsteværelse og køkken. Bygningen var dog betydeligt mindre end skolen i Skærbæk. Man fik tilbudt en grund ved Vasevej på godt 6000 kv.m. for 800 kr., og byggeriet blev anslået til godt $10.000 \mathrm{kr}$.

Koopmann var dog meget betænkelig, ikke mindst fordi det kneb for forældrekredsen at enes. På et møde i Gånsager $9 / 5$, hvor også dr. Edert og arkitekt Krogh-Haust var til stede, forelagde Koopmann sagen »usminket«, som han skrev i sit referat. Forholdene var betænkelige, forældrene var meget fattige og sad økonomisk usikkert, og Schmidt-Wodder havde opfordret til den yderste forsigtighed. Han var meget usikker over for et byggeri, men på den anden side var det nødvendigt med nye lokaler til skolen. Man burde derfor bygge, så huset kunne bruges til beboelse. Det ville gore det lettere at afhænde det, hvis det blev nødvendigt. Dr. Edert var enig i betænkelighederne, men gik ind for byggeri. Og da det var ham, der sad på pengene, blev det resultatet af mødet. Der sattes en overkant for de samlede udgifter på $12.200 \mathrm{kr}$., hvoraf selve byggeriet højst måtte andrage 11.000. Fra Jugendspende kom 4.500 kr., 6.000 låntes hos Kreditanstalt Vogelgesang, og Nordschleswigsche Gemeinde ydede et mindre tilskud. Slesvig stift lovede at bekoste en hestestald, så folk kunne få dyrene under tag, når de kom til gudstjeneste i skolestuen. Senere gaver og tilskud, bl.a. til dækning af renter og afdrag, bevirkede, at skolebygningen stort set var omkostningsfri. Lokale håndværkere fik arbejdet overdraget, og 30/7 var der rejsegilde.

Nordschleswigsche Zeitung berettede, at der var over 20 vimpler og kranse, ja selv fra den danske skole kom »ein hübscher Kranz«. Om aftenen var der kaffebord hos Grundt, hvor 40 deltog, herunder gæster fra Skærbæk og Arnum.

To måneder senere blev skolen taget i brug, og 15/10-1933 fandt indvielsen sted med ca. 250 gæster, så der har været mere end trængsel i det relativt lille lokale, betydeligt mindre end i Skærbæk. Efter en fællessang bød formanden velkommen, og pastor Horstmann holdt andagt. Folkeligt arbejde og kristendom hørte sammen, sagde han. "Hvis de adskilles, er det ude med os. Hvis vi derimod følger Guds kald, forbliver det tyske mindretal urystet og kan ikke ledes på gale veje«. Derefter talte Koopmann. Der havde været mange betænkelig- 


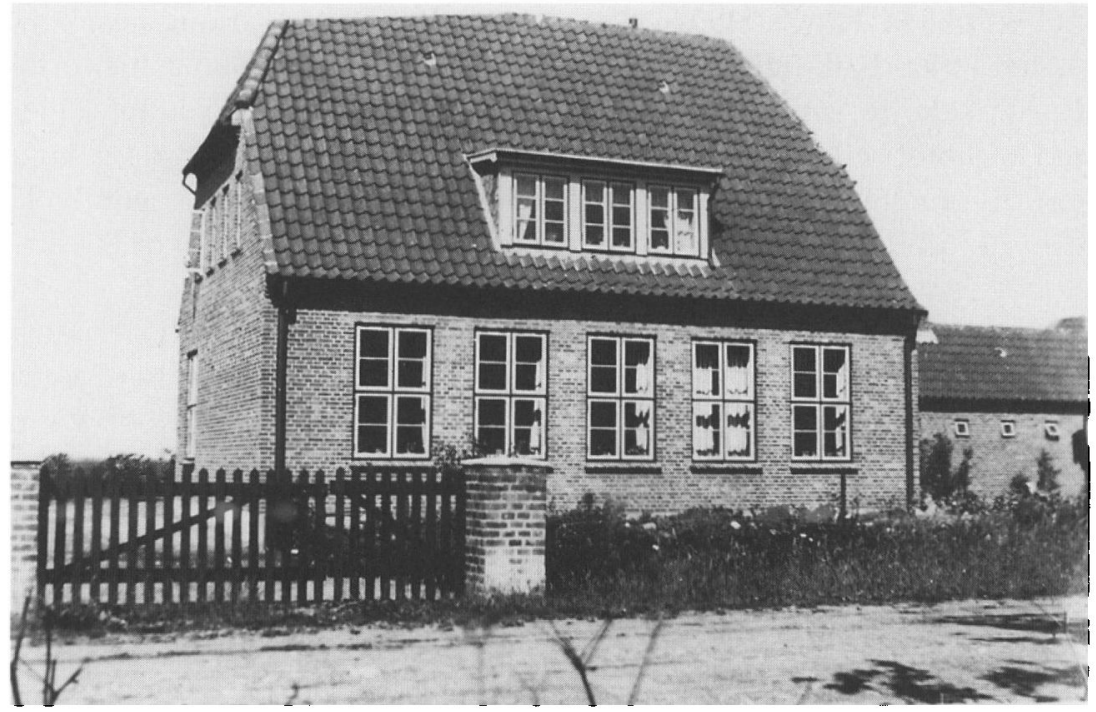

Gånsager tyske skole, 1933. Th. hestestalden. Foto: Lydia Wohlenberg. Skærbæk Museums billedsamling.

heder ved grundlæggelsen af denne skole, sagde han, men "lægger man hånd på et værk, som skal række ind $i$ fremtiden, er det ikke nok med kold beregning. Da skal man have tiltro til fremtiden. Vi har vovet at bygge dette ganske vist yderst beskedne skolehus, fordi vi har en fast tro på vort folks fremtid i Nordslesvig. Det har aldrig været let at svømme mod strømmen, og også her har vi måttet overvinde skjult og åben modstand, som til tider syntes uovervindelig. Men vi har en fast tro på vort folks og vor egen fremtid. Vi stoler på vort folk og dets Fører. De lader os ikke i stikken. Vi er først forladt, når vi opgiver os selv. Men det har vi ikke tænkt os. $\mathrm{Og}$ det har de tyske i Gånsager ikke tænkt sig“. De danske, som i 1920 glædede sig over, at der næsten ingen tyske stemmer var i pastor Schmidts sogn, måtte nu se i øjnene, at tyske bønder havde slået sig ned som nybyggere i Gånsager, og at de ikke ville opgive deres nationale overbevisning, men bevare den og holde den hellig for deres børn. »Man skifter ikke nationalitet, som man skifter skjorte«. Den, der gjorde noget sådant, var en "Gesinnungslump«.

Rektor Boysen fra Meldorf i Ditmarsken bragte en hilsen fra de slesvigholstenske lærere. "Troen på det tyske folk er urokkelig, og frem for alt har vor Fører igen gjort denne tro stærk«, sagde han, og 
rektor (højskoleforstander) Zietz fra fadderskabsbyen Lunden lovede at hjælpe skolen, hvor man kunne.

Derefter var der kaffebord på Gånsager kro, som vist aldrig tidligere havde huset en så stor forsamling, mente Nordschleswigsche Zeitung. Salen kunne ikke rumme dem alle. Her talte Schmidt-Wodder, som mindedes sine 24 år som præst $\mathrm{i}$ Vodder sogn. Danskerne havde bekæmpet ham, fordi han indførte tysk gudstjeneste. Men kampen havde også betydet, at danskerne så på ham med agtelse. Han håbede, at der ville komme gode tyskere ud af skolen. »Hvis vi står sammen i svære tider, vil lysere dage oprinde. Fra denne lille skole vil der sprede sig lys vidt ud, hvor tyske er forsamlet. Thi tyskheden har en virkende og samlende kraft«, sluttede den tyske folketingsmand. Overlærer Hansen fra Haderslev talte om den tyske skoles opgave og om det nye Tyskland, den nationale tanke og »det tyske folks mandige Fører «. Til sidst takkede skolens formand, gdr. Paulsen. Han sluttede under stort bifald: "Vi står på en fremskudt post, men vi er vant til stormen og står fast«. De danske aviser bragte korte referater efter Nordschleswigsche Zeitungs reportage, og i Flensborg Avis skrev lærer Jens Grosbøl fra Vodder skole, at selv om Koopmann sagde, at "pastor Schmidts tanker har sejret«, så »kan vi, der kender forholdene, forsikre, at for de fleste mennesker $i$ Vodder sogn er hans tanker som »frø af ugræs«.« Det har nok glædet Koopmann mere, at indvielsen nævntes $i$ et så fjernt og betydeligt organ som Frankfurter Zeitung som tegn på tyskhedens fremgang.

\section{Skærbæk skole i lærer Rahlfs tid}

For at blive ansat ved de tyske privatskoler skulle man underskrive en "Anstellungsvertrag « (ansættelsesoverenskomst), der i hvert fald fra slutningen af 1930 'erne bestod af en fortrykt formular, hvor blot lærerens navn, stedet o.lign. indføjedes med håndskrift. Det hedder heri, at læreren "forpligter sig til at vie al sin kraft til privatskolen, ligesom man også, så vidt det kan ske uden at skade denne hovedopgave, uden yderligere godtgørelse skal tage sig af ungdommen, som har forladt skolen og i det hele taget $i$ enhver retning tjene det tyske kulturarbejde«. Læreren kunne afsættes uden forudgående varsel, hvis han tilsidesatte sine pligter eller gennem sin vandel $i$ og uden for embedet viste sig uværdig til den tillid og agtelse, som det krævede af ham. Schulverein skulle føre tilsyn med undervis- 


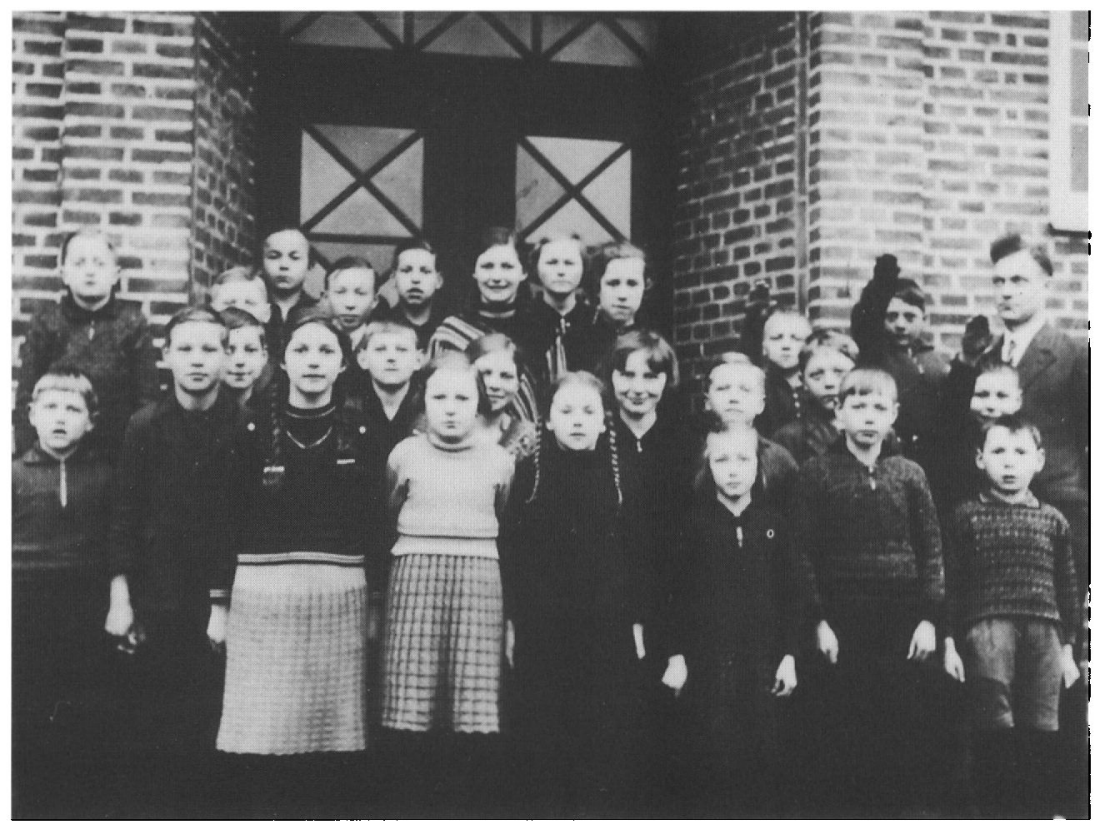

Lærer Andreas Rahlf med elever foran skolen $i$ Skærbæk 1934/35. Bemærk de to drenge til højre, som heiler. Skærbæk Museums billedsamling.

ningen og optræde som mægler ved uoverensstemmelser mellem de lokale og læreren.

Den første lærer i Skærbæk var som nævnt Andreas Vilhelm Rahlf. Han passede skolen samvittighedsfuldt, selv om Koopmann i begyndelsen ikke var tilfreds med børnenes præstationer, og ved sin første inspektion knap tre uger efter indvielsen noterede, at elevernes standpunkt ikke var godt. Det gjaldt de almindelige skolefag, og det gjaldt i særdeleshed deres tyskkundskaber, hvad der ikke kunne undre ham. Han indskærpede lærer Rahlf, at han ikke måtte lade en elev svare på dansk uden at gentage svaret på tysk. I det hele taget skulle han lægge stor vægt på at snakke med børnene. »Uden flittig samtale kommer de tyske vendinger ikke på tungen. At tale tysk og atter og atter tysk må være parolen. « Der var nu 31 elever fra 16 hjem. Koopmann håbede, at tallet snart ville stige kraftigt.

Det gik dog fremad, og 29/9-31 skrev han, at Rahlf arbejdede med stor flid og havde nået et anerkendelsesværdigt resultat. Samtidig glædede han sig over de livlige børn.

Rahlf var måske ikke et udpræget ordensmenneske, for få dage 
efter indvielsen indskærpede Koopmann, da dr. Edert og »en herre fra Berlin« ville besøge skolen, at han skulle sørge for, at »alt er i orden og indkørslen fri«. Og ved inspektionen 29/9-31 påpegede han, at der var uorden i skolestuen: "Bolden lå i kulkassen ved kakkelovnen; den skal opbevares køligt, ellers er læder og gummi snart ødelagt. « De billeder, skolen havde fået som gave ved indvielsen tre måneder tidligere, var stadig ikke hængt op, og »billedmappen må ikke ligge på gulvet. Hvis hr. Brügge (fra Jugendspende) havde været med, havde han fået et dårligt indtryk, og De ville næppe have fået mere fra ham".

Først i november skrev Schmidt-Wodder til Koopmann, at to tyske spejdere fra Tønder havde besøgt skolen, hvor de ikke havde været tilfreds med den modtagelse, Rahlf havde givet dem. De havde hverken fået kaffe eller aftensmad. Men det værste var, at de beskyldte ham for at "prygle børnene, så de ofte kommer blodige hjem«. Flere forældre skulle have meldt deres børn ud af skolen af samme grund og andre forholdt sig tøvende. Men det var selvfølgelig svært at bedømme, tilføjede pastor Schmidt.

Så snart Koopmann havde modtaget dette brev, skrev han til Kohl i Skærbæk. Han havde ved sit sidste besøg været godt tilfreds med undervisningen, men kunne naturligvis ikke bedømme forholdet mellem lærer og forældre, eller om han tog for hårdt på børnene. Det kunne kun forældrene sige. Om nødvendigt måtte der holdes et forældremøde, og »jeg må den lange vej til Skærbæk«. Han sluttede: "Skolen må ikke lide under, at læreren ikke har den rette måde at omgås forældrene på.« Han satte sig også i kontakt med Rahlf, som oplyste, at han ikke kunne med befolkningen i almindelighed, men kun følte sig hjemme i en lille kreds. Koopmann indskærpede derfor, at "vore lærere må kunne omgås hele forældrekredsen«. Han måtte ikke slutte sig til en enkelt gruppe og derved komme i modsætning til de andre. Det var ikke altid let, men sådan var nu en gang vilkårene, for at arbejdet kunne lykkes. Ikke kun undervisningen i skolen, men også alt andet arbejde i tyskhedens tjeneste måtte bæres af lyst og kærlighed. "Det er måske besværligt, men der er ikke andre måder.« Nu skrev en af forældrene til Koopmann og tog Rahlf $i$ forsvar. Børnene havde god fremgang, og hvad læreren foretog sig i sin fritid, kom vel ikke Schulverein ved. Hvem han ville omgås, måtte være hans egen sag. Hvis de forældre, der sendte deres børn fra en skole til en anden, vidste, hvor store forandringer de kom ud for, ville de 


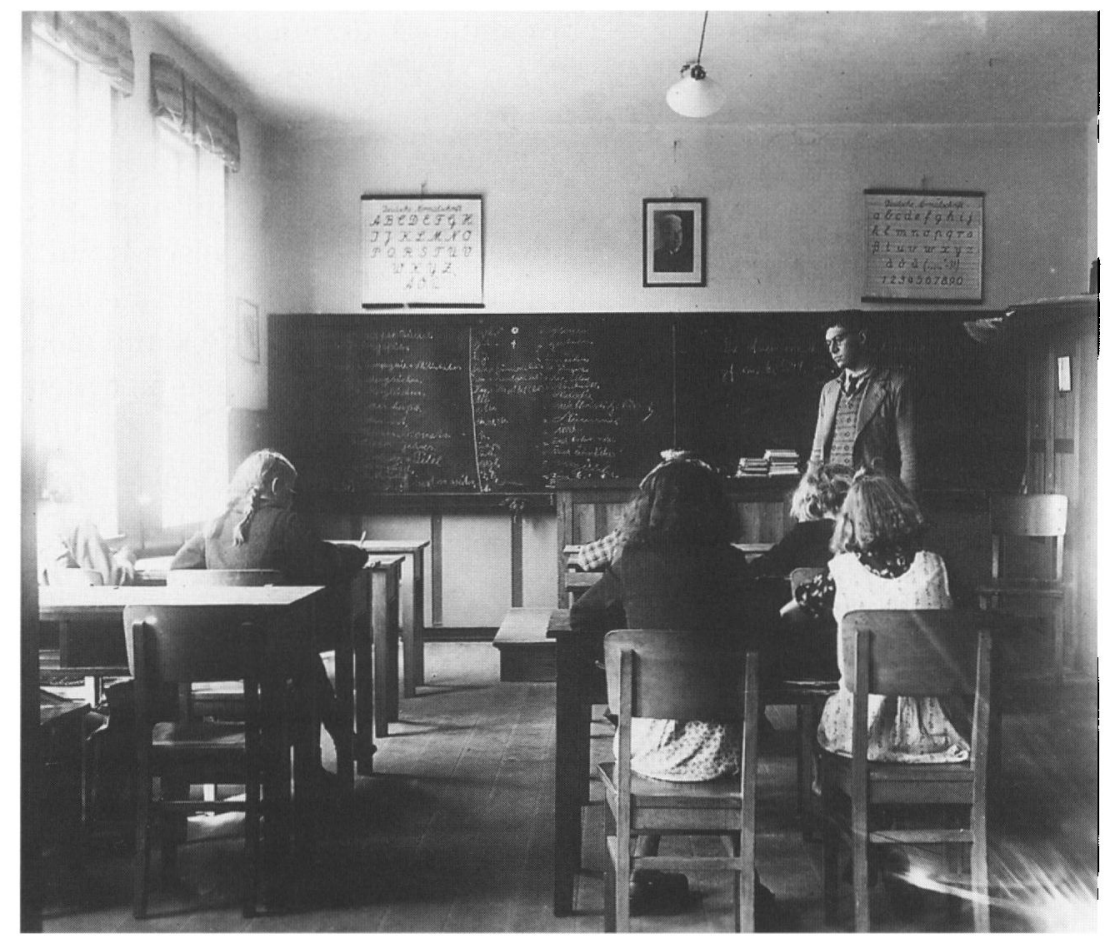

Klasseværelset $i$ Skærbæk skole. Læreren er sandsynligvis Andreas Rahlf. På væggen et fotografi af rektor Koopmann. Foto i Institut for sønderjysk Lokalhistorie.

tænke og handle anderledes. Det var $\mathrm{i}$ den ånd, sagen burde behandles på det kommende forældremøde, skrev denne far. Han ønskede ikke, at børnene skulle være gennemsnitsmennesker, tilføjede han, men forventede, at de blev åndeligt vakte, og derfor måtte lærerens hænder ikke bindes.

3/12 kom Koopmann til Skærbæk. Efter et besøg i klassen mødtes han først med Rahlf og hans kone. Rahlf havde glemt, at det var tilliden, der holdt forældrekredsen sammen, sagde han og rev ham vægringen ved at tage til Gånsager i næsen og bebrejdede ham, at han ikke gjorde nok for dem, der var kommet ud af skolen. Selv om man ikke var sportsmand, kunne man godt nu og da samle ungdommen.

Derefter talte han med Kohl, som beklagede sig over, at Rahlf ikke besøgte forældrene, ja, han hilste end ikke altid på dem. De danske lærere var mere høflige. Men der var især klager over prygleriet. Han 
slog så meget, at fire børn var blevet udmeldt af den grund. Kohls egen søn var blevet slået, så han havde haft åbne sår på benene 14 dage efter.

Derefter mødtes parterne, og Kohl fremførte sine anklager. Rahlf forsvarede sig ikke med hensyn til slagene, noterede han, det måtte altså være sandt. - Prygl var en falliterklæring, som kun undtagelsesvis kunne forsvares pædagogisk, indskærpede Koopmann, som havde bemærket, at kæppen lå fremme på katederet. Hvis Rahlf ikke straks ville brænde den, burde han gemme den så langt væk, at den skulle hentes inden brug. Derved ville han opdage, at han så godt som aldrig havde brug for den.

En del af børnene havde en lang skolevej, og nogle forældre stillede som betingelse for at melde deres børn i skolen, at de fik stillet cykler eller anden form for befordring til rådighed. Så vidt det fremgår af korrespondancen, bevilgedes mindst ni cykler til elever ved Skærbæk skole; børn fra Brøns og Randerup fik betalt kort til tog og rutebil; og der førtes lange forhandlinger om køb af en ponyvogn med hest til nogle børn fra Gasse. Det endte vistnok med, at de blev kørt ind til skolen med taxa. Husmanden fra Frifelt fik betalt hest og vogn, så børnene kunne køre til Gånsager. De var slemt forfrosne, når de kom sådan en vintermorgen $i$ kulde og sne, mindes Hans Grundt. Da en fader søgte om tilskud til reparation af børnenes cykler, slog Koopmann sig i tøjret, det var et farligt område at bevæge sig ind på, men sagen endte med, at faderen fik $50 \mathrm{kr}$. Og da Frifeltmanden ønskede penge til at reparere vognen, fandt Koopmann, at det var en »ubillig fordring», men han fik alligevel et beløb. Der blev i mindst to tilfælde givet direkte støtte til familier, den ene gang (i Gånsager) til sengetøj. Og i flere tilfælde skrev forældre til Schulverein, at de godt ville sætte deres børn i tysk skole, hvis man ville hjælpe dem til lån i Kreditanstalt Vogelgesang.

Fr. Christensen afviser indigneret $\mathrm{i}$ »Aufbau deutscher Schulen ...", at henved tusind børn (som hævdet fra dansk side) havde fået foræret en cykel for at kunne komme i tysk skole. Det var højst sket i 25 tilfælde, skrev han. Men i så fald vedrører altså over en tredjedel af disse tilfælde skolen i Skærbæk!

I marts 1934 spurgte Rahlf om betingelserne for fast ansættelse, men Koopmann svarede, at det kunne ikke komme på tale, med mindre han indgik i prøjsisk statstjeneste. Det fik Rahlf til at stille en række skarpe og - må det synes - relevante spørgsmål: Kunne tyske 
lærere i Nordslesvig slet ikke få fast ansættelse? Var de på den måde uden for pensionsberegningen? Ville der altid stå en stilling klar sydpå, når man måtte ønske det? $\mathrm{Og}$ ville tjenestetid i Nordslesvig så tælle med i deres anciennitet? Koopmann svarede kort, at man efter ti års tjeneste var pensionsberettiget, og at han gjorde alt for, at de tyske lærere i Nordslesvig ville få samme retsstilling som lærere syd for grænsen.

Det har derfor næppe været helt uvelkomment for Rahlf, da han 12/9-1935 fik brev om, at »højt betalte lærerkræfter« af sparehensyn skulle sendes sydpå. Han måtte derfor pr. 1/10 overtage en stilling "i riget«. Fire dage senere kom der brev om, at han skulle tiltræde en stilling ved 6 . Drengeskole $\mathrm{i}$ Kiel, og at familien ville få anvist en bolig ca. 10 minutters gang fra skolen.

En af de første dage i oktober modtog Koopmann brev fra en tilsyneladende yderst tilfreds Rahlf, hvori han havde den glæde at meddele, at han var kommet godt i gang i Kiel, og at familien havde det godt.

\section{Hansen og Hauschildt}

Hans efterfølger, unglærer Helmut Hansen (født 1/12-1911), tiltrådte vikariatet i Skærbæk 8/10-1935. Derved sparede Schulverein o. 200 kr. om måneden. Hansen skulle have 200 kr.; Rahlf havde med efterhånden fire børn fået næsten det dobbelte.

Han faldt hurtigt til, skrev Hansen til Koopmann 17/10. På en Gemeindeabend havde han haft lejlighed til at hilse på forældre og bestyrelse. Og 5/12 meddelte han rektoren, at amtsskolekonsulent Nic. Svendsen havde været på besøg i to timer, hvorefter han havde ytret sin tilfredshed med såvel undervisningen som skolen i det hele taget.

Da Hansen 26/3-1936 fik besked om med fire dages varsel at overtage en anden stilling, mens unglærer Walter Hauschildt skulle til Skærbæk, gjorde han oprør. Han nægtede at følge ordren og hævdede, at der ingen forståelse var i Skærbæk for nødvendigheden af et skifte, ligesom 13 forældre, der repræsenterede 28 af skolens 32 elever, anmodede om at beholde ham, samt at han personlig følte det som en »krænkelse og nedvurdering af min lærergerning«. Han sluttede med at opsige sin tjeneste i de tyske privatskoler i Nordslesvig, "hvis ikke Skærbæk får en ældre og erfaren (dienstälterer) lærer, eller jeg kan blive«. 


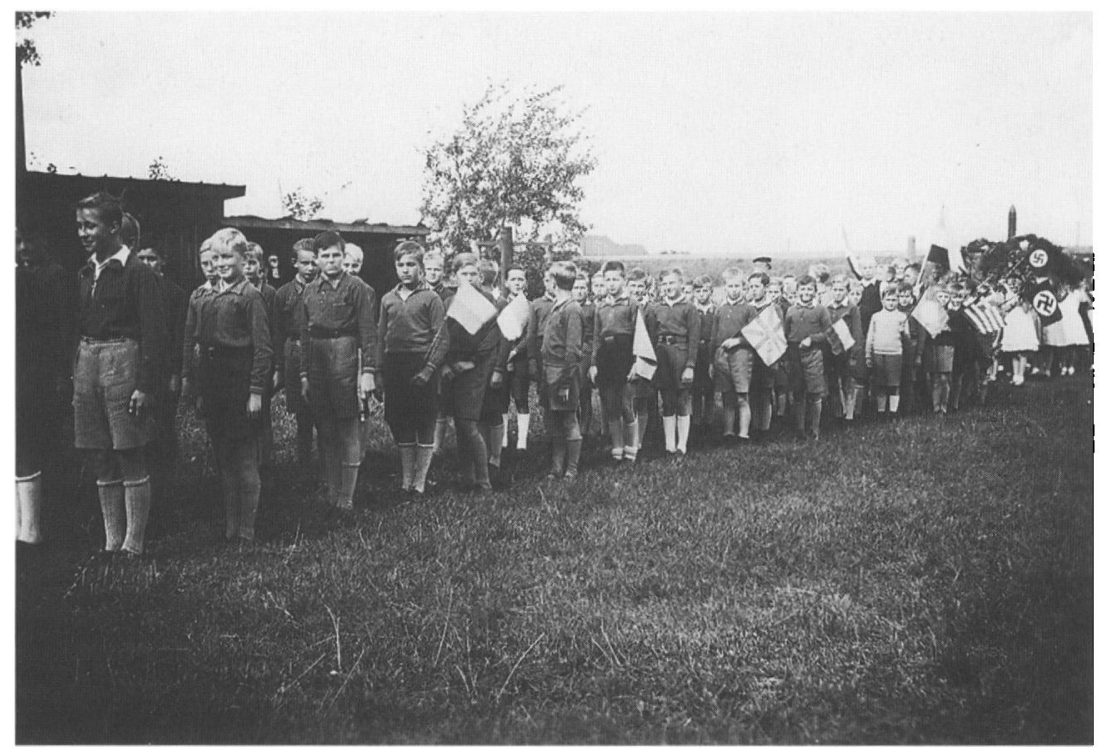

Børnene opstillet til indmarch ved sommerfesten $i$ den tyske skole i Skærbæk 1937. Flere af drengene er $i$ uniformlignende påklædning. Bemærk hagekorsflagene. Foto $i$ Adeline Hauschildts album. Skærbæk Museums billedsamling.

Koopmann svarede iskoldt, at Hansen havde misforstået det hele. Der var på ingen måde tale om en forflyttelse, for han havde jo slet ingen stilling, han kunne flyttes fra, da det var blevet gjort ham klart fra begyndelsen, at han kun var vikar. "Jeg skylder Dem ikke noget", sluttede Koopmann. Derefter parerede Hansen ordre, og der faldt atter fred over landet.

Den 21-årige Hauschildt, som overtog posten i Skærbæk, var født i Tønder 1915. Han flyttede ind i lærerlejligheden sammen med sin mor, Magda Hauschildt, der førte hus for ham og tog sig af undervisningen $\mathrm{i}$ håndarbejde. Søsteren Adeline, der gik på pigegymnasiet $\mathrm{i}$ Slesvig, flyttede senere ind hos dem, og da man efter nytår 1937 begyndte at tale om en børnehave i tilknytning til skolen, foreslog broderen, at hun tog en kort supplerende uddannelse, så hun kunne lede den. Den blev dog ikke til noget, og Adeline Hauschildt blev i stedet sygeplejerske.

I Skærbæk fik Hauschildt den første tid et godt forhold til den lokale skoleforening. Den 9/11-1936 skrev formanden til Koopmann, at han var "meget elsket«, og man havde det indtryk, at han helt og 


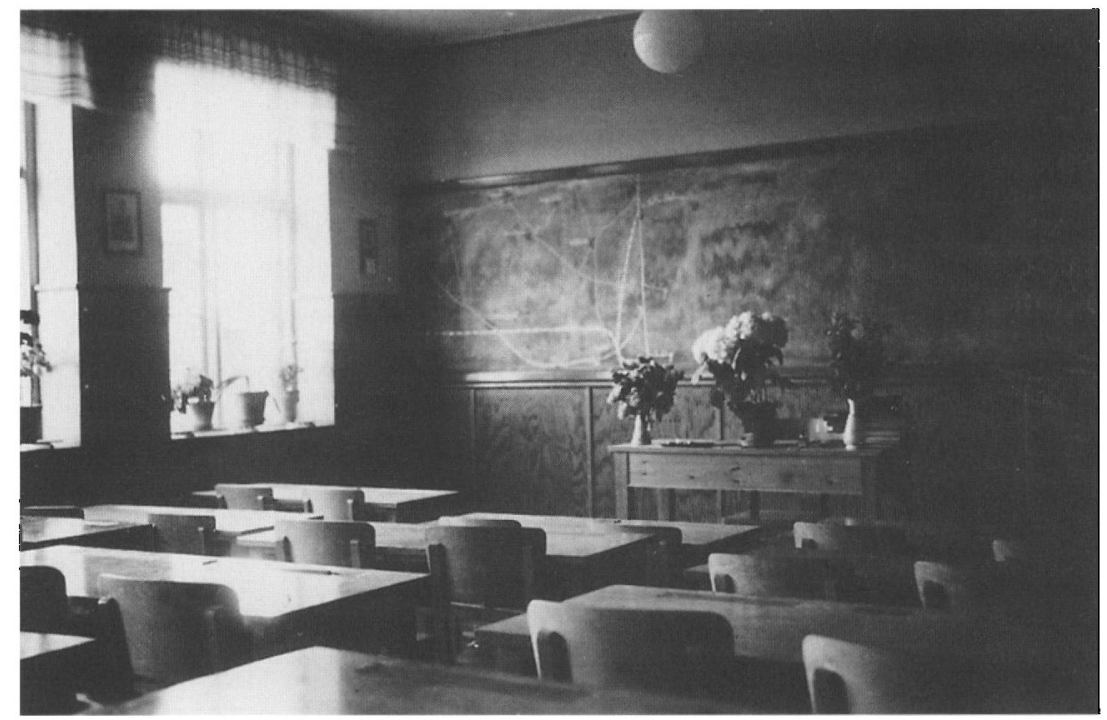

Klasseværelset $i$ den tyske skole $i$ Skærbæk, muligvis fotograferet på Walter Hauschildts forste skoledag (blomsterne på katederet). Foto i Adeline Hauschildts album. Skærbæk Museums billedsamling.

holdent viede sig til sagen. Man var også meget glad for hans mor, som på glimrende vis tog sig af børnene og ydede et fortrinligt arbejde i Husmoderforeningen (Frauenbund). Han håbede og troede, at det ville lykkes dem at stille skolens anseelse i et bedre lys.

Men en måned senere (10/12) var Koopmann ude med riven. Han "erfarede til sin skræk", skrev han, at Hauschildt ikke kunne klare de lovpligtige 246 skoledage $\mathrm{i}$ året. Hvis det skyldtes den sygdom, han havde været igennem tidligere på året, kunne han jo have taget de manglende dage fra sommer- eller efterårsferien. Men han var blevet endnu mere chokeret, fortsatte Koopmann, over at erfare, at Hauschildt havde henvendt sig til Nic. Svendsen, før han havde talt med ham. Det var meget ubetænksomt gjort, for "med amtsskolekonsulenten har De tjenstligt overhovedet intet at gøre. De skal i hvert enkelt tilfælde forhandle med mig! « Læreren svarede ydmygt, at han havde været hos Svendsen i andet ærinde og da i forbigående næunt, at han måske kom til at mangle en dag eller to. Derfor ville han nu rykke juleafslutningen fra den 22. dec. til den 24., og så var alt i orden.

I løbet af 1938 besværede bestyrelsen sig over, at Hauschildt var for egenrådig, og umiddelbart efter juleferien kom denne utilfredshed 
til åbent udbrud. Formanden Carl Sturm skrev til Koopmann, at Hauschildt ikke havde forstået at vinde børnenes hjerter gennem kærlighed og respekt, og han kunne ikke sætte sin autoritet igennem. Det ville være bedre med en ældre lærer, fortsatte Sturm og tilføjede: „Oftere og oftere hører man fra forældrene: Det var nu helt anderledes hos hr. Rahlf «. Skærbæk slap nu let af med Hauschildt, for han havde allerede sagt op pr. 1. april 1939, da han ønskede at studere videre. Der var derfor god tid til at finde en afløser. Bestyrelsen enedes om Bruno Thaysen, som den kendte fra et kort vikariat i sommeren 1936, og 1/4-1939 overtog han embedet.

\section{Bruno Thaysen}

Indsættelsen af Bruno Thaysen fandt sted den 1. april 1939 kl. 8.45. Det mærkelige tidspunkt skyldtes, at Koopmann skulle videre til indsættelser i både Sdr. Sejerslev og Tandslet samme dag. Så man kan roligt sige, at den efterhånden 69-årige mand ikke sparede sig selv. Kun 14 dage senere døde han. Under indsættelse af en lærer i Toftlund blev han ramt af et ildebefindende og straks kørt hjem til Tinglev. Her døde han kort efter ankomsten. Som Fr. Christensen siger, styrtede han "i selen “.

Thaysen var stærkt berørt af dødsfaldet og lod en mindeartikel $i$ Nordschleswigsche Zeitung indramme og hænge op i skolestuen. Heri fremhævedes Koopmanns indsats for opbygningen af de tyske privatskoler. Han havde været et lysende forbillede, stod der. Han havde haft en dyb og ægte kærlighed til sin slesvigske hjemstavn; han følte, han havde en opgave og en hellig forpligtelse til at føre den igennem. Artiklen konkluderede: "Hans hjerte slog derfor i glæde og stolthed det nye Tyskland og dets store Fører i møde, på hvis 50 års fødselsdag (21. april) den slesvigske jord modtog ham. Wilhelm Koopmann var Adolf Hitlers begejstrede følgesvend." Det var Bruno Thaysen også. Ved siden af undervisningen giorde han en stor indsats $i$ ungdomsarbejdet, og allerede et par måneder efter ankomsten til Skærbæk blev han »Kreisführer der Jungenschaft«, d.v.s. formand for den tyske drengeorganisation i Tønder amt. I februar 1941 deltog han i en »Føringslejr« i Bylderup (»dagen fratrækkes påskeferien«), og i juni havde han skaffet vikar i en uge, så han kunne komme til "Reichskampfspielen der $\mathrm{HJ}$ « (Hitler Jugends landsstævne). Da Landesjugendführer Jef Blume indkaldtes til den tyske hær, blev Thaysen konstitueret som stedfortrædende landsungdomsfører. 


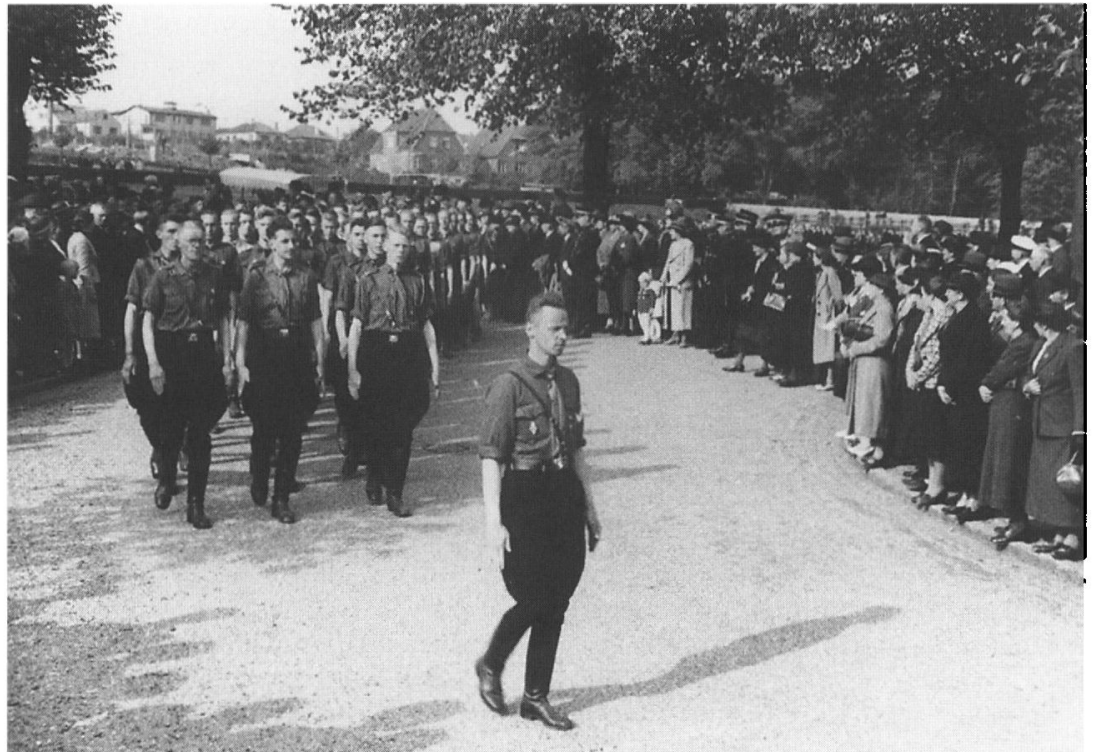

Deutsche Jungenschafts indmarch til parade $i$ Haderslev 1936/37. Forrest går Landesjugendfuihrer Jef Blume. Bag ham ses i forste rode Walter Hauschildt, Hanns-Christian Jessen og Peter Kragh (Tinglev). Foto i Adeline Hauschildts album. Skærbæk Museums billedsamling.

Samtidig var han en fremragende lærer, og efter en visitats i 1942 skrev Koopmanns efterfølger, Schulrat Christen Elholm, Aabenraa, der tidligere havde ledet den tyske mellemskole $i$ Tønder, at børnene var forbavsende godt oplært. I geografi viste nogle af dem en rent ud forbløffende viden. Lærerens "holdning « og disciplinen i skolen var god. Thaysen bedømtes som »en overordentlig dygtig, flittig og interesseret lærer med usædvanlige pædagogiske evner«. I det folkelige arbejde var han ivrig og opofrende. Forholdet til forældrene og de øvrige tyske i byen bedømtes således: "På grund af lærerens personlighed og hans kompromisløse karakter kan små uoverenstemmelser ikke undgås, men i det hele er hans stilling god.« Han havde dog besvær med en børnerig landarbejderfamilie, hvor børnene tilsyneladende var stærkt forsømte og pjækkede hele og halve dage for et godt ord. Fraværsprotokollen viser, at de kun indfandt sig i skolen ganske få dage hver måned, hvis de overhovedet kom. I flere skrivelser til Schulverein beklagede Thaysen sig herover. Familien var meget fattig, hjemmet var rodet og "stank af skidt«, og forældrene havde 
tilsyneladende givet op. Børnene var snavsede og lusede, de lugtede og saboterede undervisningen, og når han henvendte sig til forældrene, var omkvædet: "Jamen, hvad kan vi gøre ved det, ungerne gør jo, som de selv vil.« De fordærvede klimaet i klassen med deres frækhed og flabede bemærkninger og var et slet eksempel for de andre børn. De var "simpelthen af mindreværdig kvalitet og begavelse", skrev han, ligesom de også "sædeligt var ganske ødelagte“. Han havde konstateret "seksuel aktivitet « hos en seksårig pige! Uden dog at præcisere dette nærmere. Og da faderen »truede med at sætte børnene i den danske skole", spurgte han Schulverein, om man ikke burde overveje, hvorvidt det i dette tilfælde var et tab. Efter hans mening ville skolen blive »befriet for en plage«. Elholm rådførte sig med »landsfører«, dyrlæge Jens Møller i Gråsten, Schmidt-Wodders efterfølger som folketingsmand. Han ville dog ikke gå med til at udelukke børnene fra den tyske skole, så længe børneværnet og politiet ikke havde skredet ind over for familien.

I 1941 indstillede Thaysen sig til 2. prøve som lærer og skrev hovedopgave om »den nye nationalsocialistiske pædagogik«.

\section{Lydia Wohlenbergs tid i Gånsager}

"Hun var bare dejlig", siger en af Lydia Wohlenbergs elever, Hans Grundt, der gik i Gånsager tyske skole 1932-35, om sin lærerinde.

Hun forstod $i$ sin undervisning at engagere bornene og tog dem om sommeren med på korte ture i omegnen, ud på heden, ind i plantagen og til det mest populære sted, de gamle karpedamme ved Renbæk fra pastor Jacobsens tid o. 1900. Der var udflugt med hestevogn en gang om året til Gram Slotspark eller Lovrup Skrøp, og årets højdepunkter var deltagelsen i Knivsbjergfesten i juni og besøg i fadderskabsbyen Lunden.

Der blev gjort meget ud af skolens julefest, som fandt sted på den sidste skoledag i december, som regel den 22. Det første år, mens man kun havde det lille lokale hos Jørgensen, holdtes den i Luthersk Missions mødesal, men så snart den nye skole var taget $\mathrm{i}$ brug, holdt man festen der. Eleverne tegnede og skrev smukke indbydelser, som de tog med hjem til forældre, små søskende og andre, som kunne tænkes at deltage.

I 1933 holdt man her en "ægte tysk julefest", skrev Nordschleswigsche Zeitung. Børnene fremsagde digte og fremførte juleevangeliet 


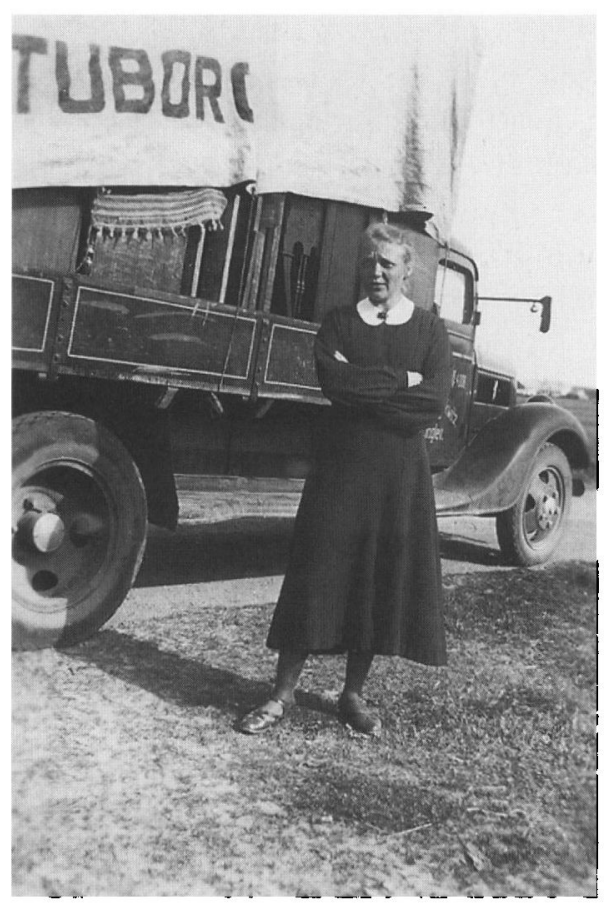

Lydia Wohlenberg foran flyttebilen, da hun forlod Gånsager 1938. Bilen er fra Tuborg-depotet $i$ Tinglev. Foto: Hans Grundt. Skærbæk Museums billedsamling.

i 7 billeder, så »vi virkelig oplever den første julefest i Betlehem«. Derefter talte pastor Horstmann, som blev hyldet, da han havde 25 års jubilæum som præst, og der var kaffebord til de 80 fremmødte. Til sidst kom julemanden. »Og de små gemmer sig i krogene, de store giver ham modigt hånden«. Der var små gaver til børnene, og efter nogle sange sluttede man.

Alligevel var en del forældre utilfredse med lærerinden. Deres klager er ikke præciseret, men nogle ville helst af med hende, og omtrent samtidig med den succesrige julefest måtte Koopmann belære dem om, at det ikke var forældrene, der ansatte læreren. Derfor havde han bestemt, at hun skulle blive, selv om hun »næppe ville anse (deres) brev for en anerkendelse".

Avisens referat fra julefesten skal måske ses i lyset heraf. Wohlenberg havde en klar forståelse af den betydning, der ligger $i$ at blive positivt omtalt. Og ved slet ikke så få lejligheder synliggjorde hun sin skole - og sig selv - ved små artikler i bladet. Hun har derfor sandsynligvis også selv skrevet det nævnte stykke, så det kunne tjene til at styrke hendes position. Hun var dog tydeligvis ikke uberørt af 
utilfredsheden. Sidst i januar 1934 skrev hun til Koopmann, at skønt hun var taknemmelig for den smukke skole og den gode lejlighed, "som gør arbejdet let«, ville hun gerne forflyttes.

Efter sommerferien 1935 var det galt igen. En af fædrene truede jævnligt med at tage børnene ud af skolen, "så snart noget ikke passer ham «, og det "går mig virkelig på", skrev hun til Koopmann og spurgte, om man egentlig ikke bare skulle lade ham gøre det, når han ikke havde mere interesse i skolen. Koopmann svarede, at faderen åbenbart førte sig frem, fordi han vidste, at skolen nødigt ville miste børnene, men det var jo også muligt, at han ville betænke sig en ekstra gang, hvis man tog ham på ordet. Så vidt kom det dog ikke.

Skolen blev opvarmet med tørv, som leveredes af hjemmene. Alle gårde og husmandssteder i Gånsager havde et stykke mose, hvorfor tørv ikke kostede penge, kun arbejde. Hver ejendom inden for forældrekredsen og den tyske forening skænkede derfor skolen et eller to læs tørv hvert år. Wohlenberg gav i en artikel i Nordschleswigsche Zeitung en munter beskrivelse af en "torvedag «, hvor alle var i mosen for at bjærge skolens brændsel. Fædrene gravede, de store drenge kørte, kvinderne og de små vendte tørvene på tørrepladsen. Og alt gik med muntre bemærkninger på plattysk og sønderjysk, skrev Wohlenberg. Gånsager skole var, iflg. artiklen, den eneste tyske skole i Sønderjylland, hvor børnene og deres forældre selv skaffede brændsel på denne måde.

Der var nok at se til. Ud over børneskolen holdt hun aftenskole for de unge, ledede sport og underviste (i hvert fald en overgang) i violinspil om eftermiddagen, stod for møder $\mathrm{i}$ Husmoderforeningen og den månedlige Gemeindeabend samt deltog $\mathrm{i}$ bestyrelsesmøder og alle øvrige tyske aktiviteter i Gånsager, ligesom hun med mellemrum var til lærermøder og weekendkurser i Schulverein. Derudover måtte hun døje med stridigheder i forældrekredsen, surhed og klager over småting. Der var ikke mange aftener fri. Det er ikke så sært, at hun ind imellem blev træt. 4/3-1936 skrev hun nedtrykt til Koopmann, at det måske var bedst, om han fandt en afløser med frisk mod og nye kræfter. På den anden side lå kvinde- og ungdomsarbejdet hende meget på sinde. Hun foreslog derfor, at han henvendte sig til formændene for skolen og ungdomsforbundet for at høre, hvad de mente.

Koopmann viste forståelse for hendes situation, for "Gånsager er et vanskeligt område«, men han ville ikke spørge formændene til råds, da det kunne skabe en præcedens og "rejse spøgelser, også for 
fremtiden, som det måske ikke ville være så let at mane $\mathrm{i}$ jorden «. Han ville åbenbart ikke, at de skulle tro, at det var dem, der bestemte. Det var måske det, Wohlenberg havde brug for at høre. I hvert fald svarede hun, at det vel var bedst, at hun blev lidt endnu. Og efter generalforsamlingen 28/3 havde piben fået en helt anden lyd. Hun havde genvundet sin optimisme. Folk i Gånsager var som forandrede, skrev hun. "Hvis jeg ikke bliver, tager de alle børnene ud af skolen." Folk var høflige og talte ordentlig til hende, så "under disse omstændigheder« blev hun gerne. Man kunne mistænke Koopmann for ad en eller anden kanal at have ladet et ord falde.

Om efteråret var det galt igen. Der var vrøvl med flere familier. En dreng var egentlig slet ikke egnet til at gå i skole, skrev hun, da han syntes uimodtagelig for elementær opdragelse og "fordærvede“ klassen ved sin opførsel. Hun måtte ikke straffe ham for faderen, og hvis drengen blev bortvist, risikerede man, at han meldte alle sine fire børn ud. Han havde allerede truet med det. Og en så voldsom åreladning kunne blive kritisk for skolen.

Få dage efter skulle to af hans børn sidde efter, men faderen indfandt sig umiddelbart efter skoletids ophør og »befalede børnene at gå hjem«. Lærerinden protesterede, han skældte ud og råbte, at børnene havde for meget hjemmearbejde, hvorefter det ene af dem, en pige, sagde, at det passede ikke. Det har været noget af en scene. "Det er utroligt, hvilken frækhed folk tillader sig", klagede hun. Koopmann støttede hende og skrev til den pågældende mand, at det var hans pligt at bruge sin faderlige autoritet over for børnene og at understøtte lærerinden af alle kræfter.

Men Wohlenberg var nær ved at give op. "Jeg er virkelig så træt af Gånsager.« Her var brug for friske kræfter, for befolkningen var "extra schwierig«. Og efter generalforsamlingen i januar 1937 skrev hun, at det var måske godt, Koopmann ikke havde overværet den. Alle var uenige, men så fortalte én en sjov historie, og alt var atter idyl. $\mathrm{Ja}$, »det er virkelig en tragikomedie«, sluttede hun. Fem medlemmer blev smidt ud af ungdomsforbundet, fordi de havde meldt sig ind i DSU (Socialdemokratisk Ungdom), der havde kaldt til kamp mod de tyske skoler. "Det er mærkeligt, at man i Gånsager og andre steder melder sig ind i danske organisationer", sukkede Koopmann. "Enten er man dansk eller tysk. Man kan da ikke tilhøre begge sider«.

Trods alle fortrædeligheder blev hun et år endnu. Ved starten af det nye skoleår 1/4-37 havde skolen ikke mindre end 20 elever, der 
alle var danske statsborgere. Et barn havde højtysk hjemmesprog, 5 talte plattysk og resten sønderjysk - eller "platdansk «, som var den hjemmetyske betegnelse for dialekten.

Men med dette skoleår var det også slut. Lydia Wohlenberg søgte og fik ansættelse på den tyske højskole i Tinglev fra 15. april 1938. Hun skulle slutte i Gånsager 8/4, men ville få løn til den 10. Der ville således blive fem dage uden løn, det måtte hun selv klare, skrev Koopmann. Det fandt hun nu var lovlig groft, at hun oven i kobet skulle trækkes i løn, fordi der var et par dage mellem de to ansættelser. Hun syntes dog hun havde udført et godt stykke arbejde. Koopmann var ubøjelig. Der kunne kun gives én løn til en skole med kun én lærer. Ville hun have løn til 15/4, måtte hun blive der så længe. Det ser ud, som om Wohlenberg valgte at resignere.

Fjorten dage senere fik hun i sit nye embede på højskolen et vrantent og vredt brev fra Koopmann. Der var et hængeparti i Gånsager vedrørende aftenskolen, hvor sløjdlæreren ikke havde fået udbetalt sin løn. Rektoren stillede i den anledning en række spørgsmål, som han krævede hurtige og præcise svar på, og sluttede maliciøst: "Det ville gøre mig virkelig ondt, hvis De selv skulle udrede dette mellemværende.« Wohlenbergs svar kendes ikke.

\section{Fadderskaber}

Det var en klar politik fra Schulvereins side, at de enkelte privatskoler skulle "adopteres" af en tysk by - i nogle tilfælde tillige af en forening eller institution -, som kunne støtte den på forskellig vis. Det gjaldt også for skolerne i Skærbæk og Gånsager. Som nævnt lovede bankdirektør Erichsen ved Skærbæk skoles indvielse, at Verein der heimattreuen deutschen Nordschleswiger i Kiel ville adoptere den og støtte den økonomisk. Men ellers er kilderne tavse om dette fadderskab.

Men skolen blev også adopteret af den lille by Tating på Ejdersted. Ved generalforsamlingen 1935 sagde Rahlf i sin beretning om skolens virksomhed, at de store havde været på en uges ophold i Tating 14$21 / 7$ og "oplevede der skønne dage«, ligesom der havde været fælles udflugt derned 1/7 og genvisit i Skærbæk 29/7. I 1936 var 25 medlemmer af skoleforeningen i Skærbæk i Ejdersted 2/8, hvor Tating havde arrangeret en udflugt til Hermann Göring-kogen for sine gæster. I 1937 besøgte amtmanden (Landrat) og flere amtsråds-(kredsdags-)medlemmer fra Ejdersted skolen, hvor bestyrelsen satte dem 

hun. Der var modtagelse på højskolen, hvor forstander Zietz og Lundens borgmester bød velkommen, og hvor gæsterne fordeltes hos indkvarteringsværterne. Efter aftensmaden var der fest på Hilles Gasthof, hvor de lokale afdelinger af Hitler Jugend og Bund Deutscher Mädel marcherede ind med faner og blev modtaget med sang og talekor. Wohlenberg, der var en ivrig fotograf, viste lysbilleder og holdt foredrag om skolen og ungdomsarbejdet i Gånsager, hvorefter højskoleeleverne opførte »Der Schweinehirt» (Svinedrengen). Aftenen sluttede med kaffebord. Lørdag formiddag var der sportsfest, hvor Gånsager tabte til Lunden-karlene i Faustball (nævebold) med 11 point, "men det var også en ulige kamp", noterer hun. Om eftermiddagen var man på udflugt til Büsum. Søndag formiddag besøgtes skolen i Lunden, hvor eleverne stod opmarcheret i skolegården, og "sammen bragte vi alle vor elskede Fører et tredobbelt Sieg Heil!« inden rundgang på skolen. Kl. 14.30 var der afgang. "Børnene var blevet så rigeligt forsynet til hjemturen af deres værtsfolk, som skulle de på en jordomrejse «, sluttede Wohlenberg sin beretning.

I september 1937 besøgte højskoleforstander Zietz Gånsager. Skolestuen var festligt smykket med hedens blomster, og børnene fortalte om Frihedskrigen (mod Napoleon 1813) og om »hededigtning « og indrammede fortællingerne med "sange fra heden«. Derefter var der kaffebord. Zietz havde ordet og forærede skolen en bog, "Der Glaube an Deutschland " (Troen på Tyskland). Den udgave af Ditmarscher Zeitung (8/9-37), som bringer dette referat, har som hovedoverskrift på forsiden: "Es ist wieder schön, ein Deutscher zu sein " (Det er atter skønt at være tysker), et citat fra Hitlers proklamation på rigspartidagen, der fandt sted samtidig.

Ved dette års besøg i Lunden 2.-4. okt. var 20 voksne og 20 børn afsted $i$ to rutebiler.

Genvisitterne fra Ditmarsken i Gånsager var i mindre målestok, og naturligvis kunne den lille forening i Gånsager ikke stille det samme på benene, som de kunne i Lunden. Der kom som regel en gang om året en eller to personbiler med gæster, som indkvarteredes $\mathrm{i}$ hjemmene, der holdtes en fest på skolen, og gæsterne kørte selv en tur til Vadehavet eller et andet sted, inden de drog hjem. I 1936 besøgte de den nyopførte Lillebæltsbro, inden de kom til Gånsager. 


\section{Skolen som kulturhus}

Det fremhæves gang på gang, at de tyske skoler selvfølgelig først og fremmest var skoler, men det pointeres samtidig kraftigt, at de også var kulturhuse, hvor tyske mennesker kunne samles om tysk kultur under snart sagt enhver form.

Derfor var også det liv og det arbejde, som fandt sted i skolerne uden for undervisningstiden af stor betydning, og det hørte til lærernes opgaver at befordre det. Man forventede, at de stod for børneforeninger (Mädelschaft og Jungenschaft) og aftenskole for unge over den skolepligtige alder, så de kunne lære det tyske sprog og finde ind $i$ et tysk fællesskab. Der skulle være husmoderforeninger (Frauenbund), som mødtes på faste ugentlige aftener, hvor man syede og strikkede, udvekslede erfaringer om husholdning og børnepasning, læste højt og talte tysk. I 1932 noterede Wohlenberg i Schul-Chronik, at man syede tøjsko af gamle lapper til børnene. Og da hun ved et besøg hos den nazistiske pastor Peperkorn i Fjolde (Viöl) i Sydslesvig indkasserede $23 \mathrm{kr}$. for et foredrag om situationen i Nordslesvig, brugtes de til garn og strikkepinde. Der skulle regelmæssigt afholdes Gemeideabend $\mathrm{i}$ reglen med et kulturelt indhold, foredrag, film o.s.v. Denne alsidige virksomhed gav lærerne et stort ekstraarbejde, som de ikke blev honoreret for. Det var en opgave, man ikke alene forventede, at de tog sig af, men som de havde pligt til at udføre.

Dette arbejde blev taget op fra første færd både i Skærbæk og Gånsager. For 1930-31 kan man gennem annoncer i Skærbæk Avis se, hvad der skete $\mathrm{i}$ den tyske forening i Skærbæk. Da man kun havde den lille skolestue i Skyttegården, holdtes møderne enten på Nørbys Hotel eller i Amtsbanegårdens restauration. 28/2 var der tysk gudstjeneste (på dansk) i kirken; 11/7 Gemeindeabend, hvor pastor Horstmann holdt foredrag på tysk; 26/9 Gemeindeabend. Rejseindtryk fra Midttyskland; $17 / 10$ Tysk aftenskole begynder, derefter en aften hver uge; 28/10 Gemeindeabend. Pastor Horstmann viser missionsfilmen »Auf Vorposten im Urwald einer friesischen Insel« (På forpost i urskoven på en frisisk(!) ø) - mon ikke der skulle stå Fiji-øerne?; 31/10 Horstmann prædiker på dansk; 21/11 Gemeindeabend. Foredrag: Af en tysk malers liv; 21/12 Julefest; 25/1: Gemeindeabend. Horstmann om "En heltesang om tyske krigsfanger" samt lysbilleder fra et krydstogt gennem Sibirien; 22/5 Gemeindeabend, intet program oplyst. 


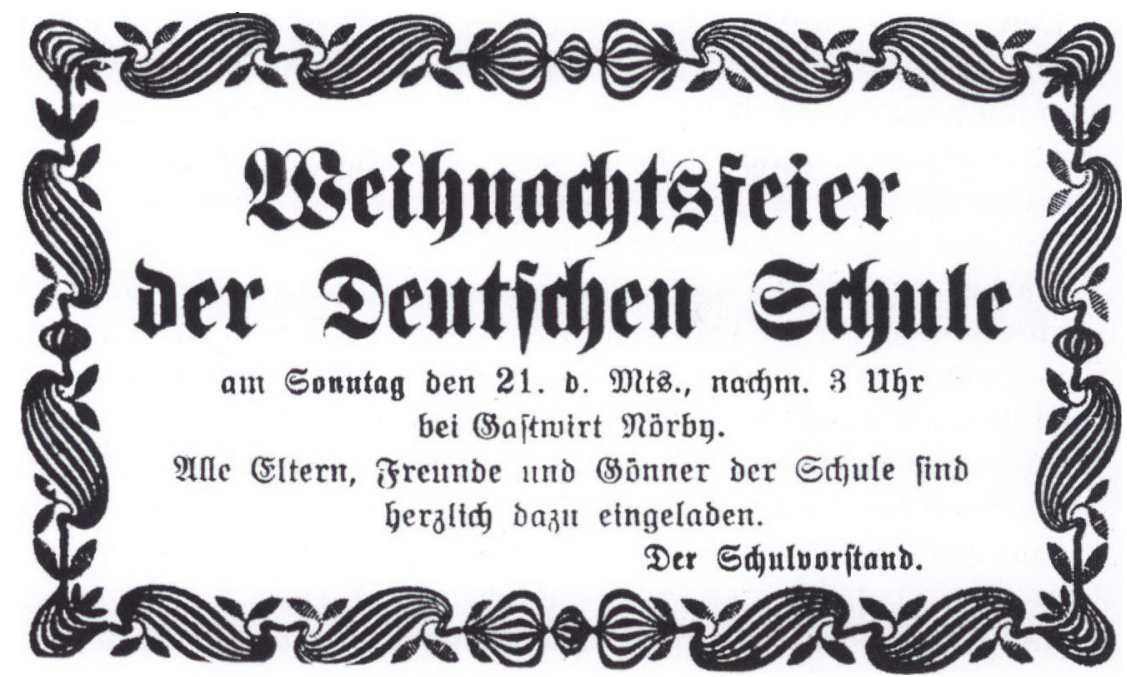

Indbydelse til julefest $i$ den tyske skole. Annonce fra »Skærbæk Avis" 1930.

23/1-32 skrev Flensburger Nachrichten, at det tyske kulturarbejde i Skærbæk var i glædelig fremgang. Læreren og hans kone havde stillet sig helt $\mathbf{i}$ den tyske sags tjeneste. Hver tredje uge holdt de Jugendabend med sang, folkedans og selskabslege plus "en dejlig kop kaffe«. Gånsagers unge deltog ivrigt, sidst havde der været 14 til stede; her må vel menes i alt, altså ikke kun gæsterne fra Gånsager. Avisen nævnte, hvem der var i Husmoderforeningens bestyrelse og oplyste, at Skærbæk "Singchor « havde ti mandlige og to kvindelige medlemmer. De havde underholdt ved julefesten. Desuden foretog en afdeling af foreningen Wandervogel små ture i omegnen. "Således arbejdes der langsomt videre for at skabe et fast grundlag for det tyske liv«. I et par tilfælde kendes trykte indbydelser med program, f.eks. til en Tysk Aften, som blev afholdt på Jernbanehotellet den 19. nov. 1932. Efter velkomstord var der foredrag ved pastor Schmidt-Wodder, hvorefter koret foredrog nogle sange. Tønders tyske amatørteater (Tonderner Spielgruppe) opførte stykket "Der verschriebene Vetter aus Bremen« inden det fælles kaffebord. Aftenen sluttede med dans.

I de fleste tilfælde har man nok nøjedes med at bekendtgøre arrangementerne gennem opslag på skolen, ligesom eleverne vel har haft sedler med hjem, som de selv har skrevet som diktat. 
Den metode brugtes i Gånsager. Der findes bevaret nogle sirligt skrevne og tegnede indbydelser til en julefest, men ellers vides næsten intet om datoer eller program for de enkelte møder, da de sjældent er annonceret eller refereret. Men af foreningens regnskabsbog kan man se, at der i 1935-36 otte gange blev afholdt Gemeindeabend, der oven i købet gav et overskud på 37,57 kr. I de følgende år var der årligt, så vidt det kan ses af regnskabsbogen, mellem 3 og 13 arrangementer, flest i 1940-41. Hans Grundt husker, at der i reglen var et møde om måneden, somme tider med foredrag, andre gange med film. Da det ikke var muligt at komme i biografen fra Gånsager, var filmaftenerne populære og trak mange folk, ikke alene fra den tyske del af befolkningen, men også mange danske mødte op, så der kunne være 75-80 mennesker samlet i skolen. Til de andre aftener kom der kun halvt så mange, næsten udelukkende fra den tyske kreds. I reglen indledte man mødeaftenerne med andagt, $i$ begyndelsen ved pastor Horstmann, senere ved pastor Raun fra Løgumkloster, hvorefter præsten eller en anden holdt foredrag om et historisk eller kulturelt emne. En gang imellem var der gudstjeneste i kirken, hvor man også holdt tysk konfirmation. I 1935, da Hans Grundt blev konfirmeret, havde pastor Raun fem tyske konfirmander i Vodder sogn, alle fra Gånsager.

Et udklip fortæller, at man den 2/9 (året ikke opgivet, men det må være 1934, en måned efter Hindenburgs død) holdt Gemeindeabend med barnedåb i den festligt smykkede skole, hvor katederet var forvandlet til alter. »Alle mærkede vist den stærke glæde ved optagelsen af et nyt medlem i vort fællesskab«, skrev avisen, som fortsatte: »I kærternes skær og under det grønt- og floromvundne billede af Hindenburg talte pastor Horstmann derefter bevægede ord til tak og eftertanke (Mahnung) i mindet om denne vor feltmarskal og rigspræsident. Det tyske folk må se det som en særlig nåde, at det i svære tider fik skænket to dygtige, trofaste og dådkraftige mænd, Hindenburg og vor Fører.« Mindehøjtideligheden sluttede med sangen: "Ich hatt' ein Kameraden, einen bessern find'st Du nicht«.

Heinrich Grundt havde 1932-33 overladt de unge en toft ved sin gård til sportsplads, og her trænedes ivrigt flere aftener om ugen især i Faustball (nævebold), et boldspil med fem mand på hvert hold, ikke ulig volleybold. Derefter benyttede man sportspladsen ved skolen. Der var så mange deltagere, at man havde to ynglingehold (en overgang endda tre) og et pigehold. Holdene deltog i sportsstævner både 
mellem de tyske ungdomsforeninger og i de nærmeste landsbyer mod danske hold. Førsteholdet var i Wohlenbergs tid ganske respekteret og vandt adskillige kampe, i 1934 blev de endog nr. 1 ved Knivsbjergfestens sportsstævne.

Både i Skærbæk og Gånsager havde man sangkor og i Gånsager også et orkester, der spillede på violin, harmonika og Zugpfeifen (»togfløjter «). De underholdt ved arrangementer på skolen.

På generalforsamlingen i Skærbæk i april 1935 oplyste Rahlf, at der havde været følgende aktiviteter i skolen: 8-12 drenge mødtes en aften om ugen til Jungsabend - der var endnu ikke nogen pigeafdeling, den kom først året efter; der havde været aftenskole 20 aftener á to timer, hvor 13 unge fik tyskundervisning; Jugendbund (ungdomsafdelingen) havde 18 medlemmer, der spillede Faustball om sommeren og om vinteren mødtes en aften hver måned til sang, foredrag, kaffe, leg og folkedans; biblioteket, som også havde hjemme på skolen, og som læreren passede, havde 410 bind, og 54 lånere havde lånt $\mathrm{i}$ alt 456 bøger; sangkoret havde haft 27 øveaftener og indøvet 12 sange, hvoraf 2 var tostemmige; der havde $1 / 7$ været udflugt til Tating, og 29/7 havde man haft besøg derfra, ligesom eleverne havde været en uge på Ejdersted og boet i venskabsbyen 14-21/7; fra 20/10 til 1/3 havde der seks gange været Gemeindeabend og fester, og der var afholdt fire tyske gudstjenester i kirken.

1930'erne igennem synes aktivitetsniveauet at have ligget på samme højde. Det vil sige, at læreren, som nærmest var forpligtet til at deltage $\mathbf{i}$ det hele, havde mindst 110 aftener besat $\mathrm{i}$ løbet af året, ud over hvad sportstræning, bibliotek, udflugter og bestyrelsesmøder krævede. Han har således i gennemsnit haft tre hverdagsaftener om ugen besat året rundt, og i vintermånederne var det vel stort set hver aften, fraregnet lørdag-søndag, som også af og til var optaget. Man kan godt forstå, at han trængte til at slappe af, og at Hauschildt et par gange udeblev fra de pædagogiske weekendkurser, som afholdtes for lærerne ved de tyske privatskoler, og bagefter måtte indkassere en reprimande fra Koopmann.

I sommerferien 1936 var 18 elever på sommerferie "i riget", de fleste i Oppenheim am Rhein, en lille by syd for Wiesbaden, lidt større end Skærbæk. Opholdet var et led i deres opdragelse til rigtige tyskere. De boede en månedstid hos ukendte "ferieforældre«, som behandlede dem godt og tog dem med på udflugter. "Men hvor jeg længtes hjem«, fortalte en af drengene, der deltog som 9-årig. 


\section{Det politiske arbejde}

At opdrage børnene i tysk ånd var formålet, men bortset fra at man naturligvis støttede mindretallets politiske ledere, især folketingsmand Schmidt-Wodder, spores der i de første år ikke nogen egentlig partipolitisk retning. Det ændrede sig efter 1933, hvor en stadigt stærkere nazificering gør sig gældende.

At Lydia Wohlenberg har interesseret sig for, hvad der skete politisk i Tyskland, og til hvilken side, hun hældede, er der ingen tvivl om. I Schul-Cronik for Gånsager tyske privatskole (en beretning om skolens liv, egentlig tænkt som en skoledagbog), som hun desværre kun førte det første år, står: »I januar 1933 levede vi af ganske hjerte med i det store omsving i Tyskland. Den 10. februar hørte vi Hitler. Nogle dage senere besøgte Boldt os, han er dansker, men nazist. Han mødte mig med ordene: »Nå, hvad siger De nu? «, da han kom ind i skolen. Og jeg kunne kun udbryde: "Jeg siger: Heil Hitler!«« Johannes Michaelsen Boldt havde den store gård Havedgård i nabosognet Rejsby og var en kendt nazist, herredsleder og folketingskandidat for Danmarks Nationalsocialistiske Arbejderparti (DNSAP), Frits Clausens parti.

Samme sommer deltog de fleste forældre og børn takket være en gave fra Flensborg byråd (overborgmester Sievers) i et stort slesvigholstensk stævne i Rendsborg 18/6. De fleste havde da ikke været i Tyskland »i årevis«, noterede Wohlenberg. Deltagerne fra Gånsager var dog noget forbavsede over talerne, fortsætter hun, da »vi i den stille landsby havde håbet, at vi efter omvæltningen (Hitlers magtovertagelse) straks kunne vende tilbage til Tyskland med flyvende faner. Nu blev det klart, at det var der foreløbig intet håb om (dass davon vorläufig nicht zu denken war).«

Ved juletid 1933 sendte børnene en hilsen til en af de ledende inden for det tyske kulturarbejde i Sønderjylland, Anne Martensen. Hun takkede $18 / 1$ for de smukke tegninger. De havde vist hende, "at I hele tiden tænker på vort Tyskland og vor store og gode Fører Adolf Hitler. Sådan må det også være, thi alle store og små børn må hjælpe til, så det i Tyskland og her hos os i Nordslesvig bliver, som vor Fører vil have det«. Rene ord for pengene!

I september 1933 havde Skærbæk besøg af fem studenter fra Den Pædagogiske Højskole i Kiel, som ved en Gemeindeabend berettede om forholdene $\mathrm{i}$ »det nye Tyskland«. Af forældrene var "nogle marx- 


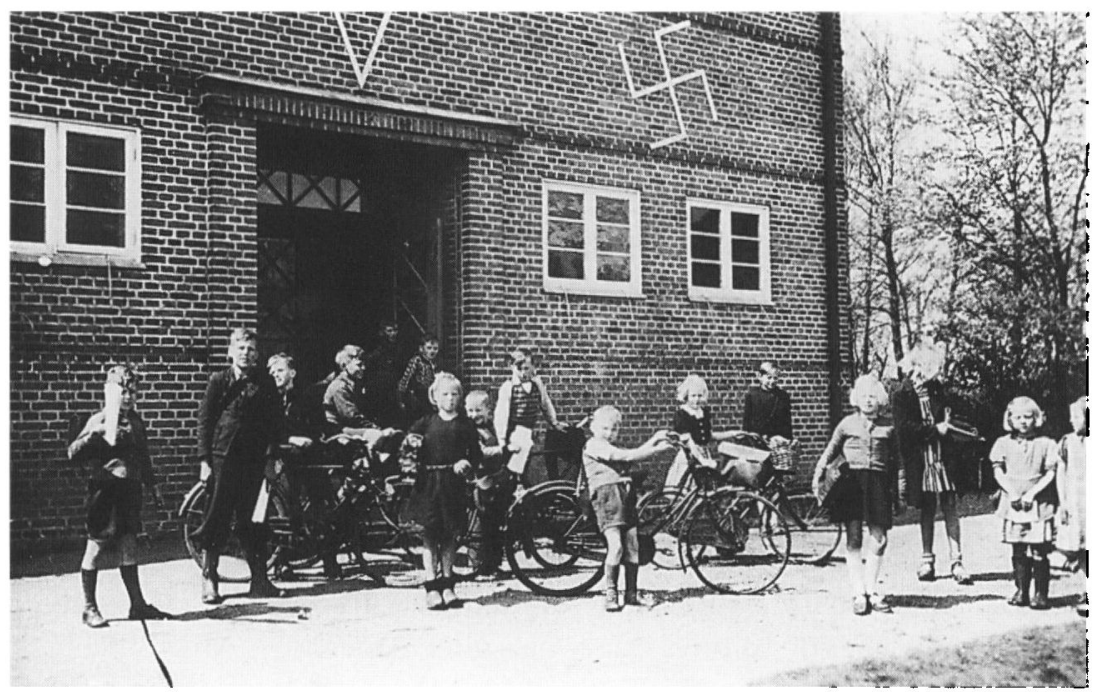

Den tyske skole i Skærbæk prydet med hagekors på gårdsiden under besættelsen. Foto $i$ Historiske Samlinger for Sønderjylland.

istisk indstillede arbejdere" udeblevet, dels af "personligt had til nationalsocialismen ", dels af frygt for reaktionen fra deres danske arbejdskammerater og arbejdsgivere, skrev Rahlf. Kun fire arbejdere var mødt frem. Men der var dog samlet 50 personer i skolestuen, herunder også nogle unge, som aldrig før havde været til et arrangement $i$ skolen. Det sidste glædede ham meget.

Student Ernst Fr. Mückel holdt foredrag om den tyske arbejder, og ved kaffebordet besvarede studenterne "forskellige spørgsmål om arbejdslejre, koncentrationslejre, SA og lignende forhold i Tyskland ud fra deres egne anskuelser. Det virkede godt som modgift mod den danske presses løgnemeldinger «. På et spørgsmål om tilskud fra Tyskland svarede studenterne, at de måtte gives ud fra "folkebiologiske« og "folkevidenskabelige« kriterier. Rahlf sluttede sit referat: "Efter afslutningsord fra lærer Rahlf, der opfordrede til at slutte sig til nationalsocialismens idé, endte aftenen.« Han undertegnede referatet med et hagekors og sit navn.

Rahlf havde tydeligvis set lyset. En måned senere blev han opfordret til at danne en partiafdeling i Skærbæk af folk fra Aabenraa, hvilket må betyde fra mindretallets nazistiske fraktion, NSDAP-N (Nationalsozialistische Deutsche Arbeiter Partei - Nordschleswig). Da 
han var tysk statsborger, spurgte han Koopmann, hvorledes han skulle forholde sig hertil. Han ville jo nødigt støde forældrene fra sig, så de meldte børnene ud af skolen. "Selv om jeg privat ikke lader nogen i tvivl om, at jeg bekender mig til Hitler og nationalsocialismen, kunne min indtræden $i$ en gruppe måske foranledige enkelte forældre til at tage sådanne skridt." Det ville dog kun dreje sig om 2-3 forældrepar, der "har en anden mening end jeg om denne sag «, mente han.

Koopmann manede til forsigtighed. Selv om det var svært entydigt at sige, hvorledes man burde forholde sig, ville han ikke selv som tysk statsborger melde sig ind i partiet, men i enhver henseende hjælpe til. Det måtte jo være så meget lettere, som han gik »inderligt ind for sagen «. Hvis man ønskede ham som foredragsholder eller lignende, var det helt $i$ orden, men det ville være klogt af forsigtighedshensyn at lade Ungdomsforbundet stå for det, "eller som en i disse sager ledende herre sagde til mig: Edelweiss eller Alperose«. Altså ikke bruge partiets navn.

I marts 1935 støttede Rahlf »af almindelige nationalsocialistiske grunde « en ansøgning fra en af skolens forældre om økonomisk støtte, hvilket fik Koopmann til at spørge, hvad han egentlig mente med det. Rahlf svarede, at det nærmest betød naturlig hjælpsomhed over for en folke- og partifælle!

Om det har spillet nogen rolle i undervisningen, er svært at sige, men i juni 1935 var han med de ældste elever i Flensborg for at se Leni Riefenstahls film »Triumph des Willens« om den nazistiske partidag i Nürnberg i efteråret 1934. Også det må have haft sin virkning på læreren, for i september søgte han om fri for at komme til Nürnberg og selv deltage i dette års partidag. Det lykkedes dog ikke. Det gik Wohlenberg på samme måde i 1937, da hun gerne ville flytte en sommerferieuge for at kunne rejse til Nürnberg. Det kunne han ikke gå ind på, »hvor gerne han end ville«, svarede Koopmann, og da hun udtrykte sin dybe skuffelse, foreslog han hende i stedet at tage til »Reichskundgebung « (også et stort partistævne) på Bückeberg, et højdedrag ved Weser ca. $70 \mathrm{~km}$ syd for Bremen. Det ville ligge bedre for ferien.

Hans Grundt fortæller, at der ikke, så længe han gik på skolen, altså indtil april 1935, blev drevet nogen form for politisk propaganda, og der hang heller ikke noget billede af Hitler i skolestuen. Det kom først i 1936. Derimod husker han tydeligt, at der var fotografier af Hindenburg og - Koopmann(!). Men da skolen i marts 1934 fik til- 
sendt 16 bind fra det tyske hovedbibliotek i Aabenraa til grundlæggelse af en lokal bogsamling, kom der udelukkende bøger om Hitler og nationalsocialismen. Ved det, som Nordschleswigsche Zeitung 21/11-34 kalder "den første tyske fest i Gånsager ", tog højskoleforstander Zietz fra Lunden sit udgangspunkt $i$ et Hitler-citat, da han holdt foredrag om bøndernes betydning i verdenshistorien: "Tyskland skal være en bondestat, eller også vil det slet ikke være noget.« Og i februar 1935 viste hun »den nye SA-film« på skolen, dog kun for forældre og de unge, der var gået ud af skolen. Da hun kort efter blev indkaldt til et møde hos amtsskolekonsulent Svendsen, troede hun, at det var denne film, der stod på tapetet. Men Svendsen havde helt andre ting at tale med hende om. Bl.a. havde han fået at vide, at der blev solgt smuglercigaretter ved den tyske aftenskole i Gånsager, og at hun udspredte nazistisk propagandamateriale ved hjælp af eleverne. Smugleriet nægtede hun ethvert kendskab til, og det andet afviste hun blankt. Hun havde givet ungdomslederen nogle brochurer.

Fra oktober 1934 gik Koopmann fra at skrive "Mit deutschem Gruss« (med tysk hilsen) under sine breve over til at bruge »Heil Hitler! «, og lærerne og bestyrelserne fulgte trop. Derefter stod denne hilsen under stort set alle skrivelser $\mathrm{i}$ korrespondancen vedrørende de tyske skoler, også hvor det ser helt parodisk ud som i et brev fra 22/5-1939, der lyder i sin helhed:

»Det årlige forbrug af kul til den tyske skole i Gånsager udgør $1000 \mathrm{~kg}$.

Heil Hitler!

Käthe Jepsen Schmidt.«

I juni 1935 indberettede Wohlenberg, at der i Gånsager fandtes en NSAN-gruppe med 16 medlemmer. Der var den gang to konkurrerende tyske nazistpartier i Sønderjylland. Ud over NSDAP-N, der støttedes af mindretallets ledelse, havde NSAN (National-Sozialistische Arbeitsgemeinschaft Nordschleswig), ledet af gårdejer Jep Nielsen, Lille Jyndevad, ret mange tilhængere. Der var dog ingen uoverensstemmelser i Gånsager. »Her er kun Jep Nielsen-folk«, skrev hun til Koopmann 27/12-37. "De er ret ivrige og har endog dannet et nationalsocialistisk Jungenmannschaft « (ungdomsafdeling).

Men problemet var åbenbart reelt andre steder, hvor begge partier 
var repræsenteret i mindretallet, for 24/9-35 udsendte Koopmann en rundskrivelse til alle tyske privatskoler, hvori han forbød lærerne at optræde som ledere, talere eller indkaldere ved nogen partiaktivitet. Ligeledes var det forbudt at fremsætte bemærkninger i undervisningen, som kunne opfattes politisk krænkende i hjemmene, hvad enten de tilhørte den ene eller den anden gruppe. Lærerne skulle tværtimod virke samlende for hele den tyske folkegruppe, påpegede han. De måtte naturligvis gerne have deres egen mening, blot de holdt den for sig selv.

På den tid var der ingen partiafdeling i Skærbæk, men "nogle fåı deltog i Gånsager-gruppens arrangementer. Om de er medregnet i de 16 , vides ikke. Walter Hauschildt var selv en ivrig nazist og gik meget op $i$ arbejdet med Jungenschaft (drengene). "Det var sådan en slags spejdere«, fortalte en af hans elever i 1992. 10/11-1938 var Stehrs søn, Rudolf Stehr jun., som beklædte en høj post inden for mindretallets nazistiske organisation, i Skærbæk for at grundlægge en NSDAP-Ngruppe.

I januar 1937 skrev Wohlenberg dybt indigneret til Koopmann, at prædikanten i Luthersk Missionsforenings søndagskole i Vodder havde bedt til Gud om, at Hitler ikke ville opruste til krig. "Det kalder man for børnegudstjeneste! « fnøs hun og ville meddele taleren, at hvis han ikke undlod den slags i fremtiden, "måtte han i pressen «. Året efter anskaffedes M. Häfners skrift om Adolf Hitler til historieundervisningen, da »forfatteren skriver børnerigtigt og letforståeligt «.

Koopmann var påpasselig med, at skolerne ikke gav anledning til uheldig omtale i den danske presse. Da han 24/2-36 i Tonder Amts Socialdemokrat læste, at "en hr. Schneidewind " havde "optrådt « i skolen i Skærbæk, bad han om nærmere besked. Lærer Hansen indberettede, at taleren ved en Gemeideabend havde endt sit foredrag med et »Heil Hitler! «, hvorefter en elev, hvis far var en »stærkt socialdemokratisk indstillet arbejder«, havde rejst sig og forladt lokalet. Skolens pedel Schneidewind havde standset ham, men drengen sagde, at han skulle skynde sig hjem, da det var blevet meget sent. Schneidewind skulle så have sagt, at den egentlige grund nok var, af drengens far var en »stor socialdemokrat«. Den børnerige familie Schneidewind, der var tyske statsborgere, rejste i øvrigt »hjem til riget« nogle måneder senere. Referatet virker bevidst neddæmpet. Men "socialdemokrat« var utvivlsomt en meget grimt skældsord i nazistiske kredse. Det var dog endnu værre at bruge ordet "kommunist«, som Skær- 
bækformanden, bogholder Bech, gjorde 3/9-43 om et bestyrelsesmedlem, der havde nedlagt sin post og ikke længere ville arbejde for den tyske sag "på grund af de seneste begivenheder«.

Med Thaysens ankomst til Skærbæk 1939 fik partiarbejdet en opblomstring i byen. Det smeltede sammen med det kulturelle arbejde, så man næppe kunne skelne, hvad der var hvad. Mens de tyske arrangementer i Rahlfs og Hauschildts tid havde været en intern affære, satte Thaysen alt ind på at gøre tyskheden synlig med store annoncer i det lokale ugeblad Skærbæk Avis og ved tæt samarbejde med besættelsesmagten.

\section{Under besættelsen}

Den tyske besættelse af Danmark den 9. april 1940 ændrede på mange måder forholdene i Skærbæk, der fik en fast garnison af tyske tropper. Bl.a. blev skolebygningen udsmykket med hagekors og en prangende indskrift i store gotiske bogstaver henover facaden ud mod Ribevej: »Deutscher Sieg an allen Fronten!« (Tysk sejr på alle fronter).

Thaysen tog straks efter besættelsen kontakt til værnemagten, og i indkaldelserne til de tyske arrangementer, både på skolen og andre steder, som oftest på Jernbanehotellet, pointerede han, at "Angehörige der Wehrmacht« (tyske militærpersoner) var meget velkomne, og at soldater $i$ uniform havde gratis adgang. Det ses første gang til julefesten på skolen i 1940.

I 1941 annonceredes 11 arrangementer, i 1942 var det seks, i 1943 otte, og i 1944 kun tre. Der kan dog udmærket have været flere, som er bekendtgjort internt. Det sidste tyske kulturarrangement, der kan dokumenteres ud fra Skærbæk Avis, er Den Tyske Skoles Dag, der afholdtes 9/7-1944 som en børnefest "med fornøjelser for voksne. - Enhver tysk bør/skal (muss) møde op«.

Der blev hyppigt vist film. I 1941 kunne man således se »den store og berømte tonefilm »Bismarck««, krigsreportagen »Sejr i vest« om krigen i Holland, Belgien og Frankrig, "Kammerater på havet« om flåden, "den berømte og elskede "Ønskekoncerten « "og den patriotiske "... rider for Tyskland «. I 1942 vistes krigsfilmen "U-både mod vest«, "Hjemkomsten " med Paula Wessly (vel krigsromantik) og lystspillene »Hurra, jeg er blevet far« og "Quax, der Bruchpilot «, begge med Heinz Rühmann. Om den sidste hedder det, at den er »for dem, som vil le ret af hjertet«. Også i 1943-44 vekslede lystspil og krigsfilm. 
Bund für deutsche Kultur (Ortsgruppe Scherrebek)

Achtung !

Achtung !

\section{Grosses}

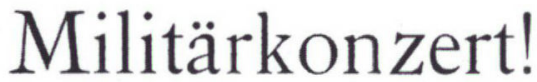

Am Sonnabend, dem 18 April im Bahnhofshotel in Scherrebek.

Die Divisionskappelle (40 Musiker) unter Obermusikmeister $\mathrm{S}$ ch e er kommt wieder zu uns.

Die Musiker bleiben bis Sonntag-mittag bei uns. Es fehlen noch einige Privatquartiere. Bitte Anmeldungen bei Lehrer T tra ys en. (Tlf. 146)

Nur Mitglieder des Bundes haben Zutritt. Wer noch keine grune Mitgliedskarte hat, muB solche vor dem 26.3. bei Lehrer Th a y sen kaufen. (Wehrmachtsangehörige brauchen keine Mitgliedskarte)

Die Mitgliedskarten müssen an dem Abend vorgezeigt werden! Nicht vergessen!

Beginn : 20 Uhr.

Eintritt : $1,00 \mathrm{Kr}$.

Kuchen für die gemeinsame Kaffeetafel mitbringen!

Zutritt für Schulkinder verboten!
E in 1 a d u n g

zu einem

Filmabend

Am Montag, dem 23. November, 20 Uhr haben wir in der Schule einen schönen TONFILMABEND.

Wer einmal recht von Herzen lachen will,

der soll sich den schönen Film

\section{"Quax, der Bruchpilot"}

ansehen.

Der berühmte Filmkomiker HEINZ RÜMANN macht in diesem Film einen unwiderstehlichen Angriff auf unsere Lachmuskeln

AuBerdem sehen wir eine neue WOCHENSCHAU.

Eintritt (mit Kaffee): $1 \mathrm{Kr}$.

Alle deutschen Volksgenossen und die Kameraden der Wehrmacht sind herzlich eingeladen.

Der Ortsgruppenleiter.

Indbydelser til filmsforevisning $i$ den tyske skole og militærkoncert på Jernbanehotellet. Annoncer i Skærbæk Avis 1941 og 1942.

I forbindelse hermed vistes de nyeste ugejournaler med fremhævelse af Tysklands triumfer på slagmarken. Derudover var der teaterforestillinger på høj- og plattysk, koncerter med tyske militærorkestre, foredrag, julefester og sportsarrangementer.

Hvor uundværlige ledelsen af Skoleforeningen end anså lærerne for at være, måtte den se i øjnene, at krigen også ville betyde indkaldelse af en del af underviserne. I 1938 havde man meddelt værnemagten, at alle de 44 lærere i Sønderjylland med tysk statsborgerskab, der kunne komme i betragtning ved indkaldelse, var "unabkömmliche" (uundværlige). Men da krigen blev en realitet, onskede en del af dem at melde sig til fronttjeneste.

Det er baggrunden for den skrivelse, Schulrat Elholm sendte alle Skoleforeningens lærere 24/5-40: »I den vældige kamp, hvori Stortyskland befinder sig, er alle lige så nødvendige på deres poster konstruktøren på Vestvolden, lokomotivføreren på sin maskine, arbejderen i ammunitions- og flyvemaskinefabrikkerne - som soldaten i 


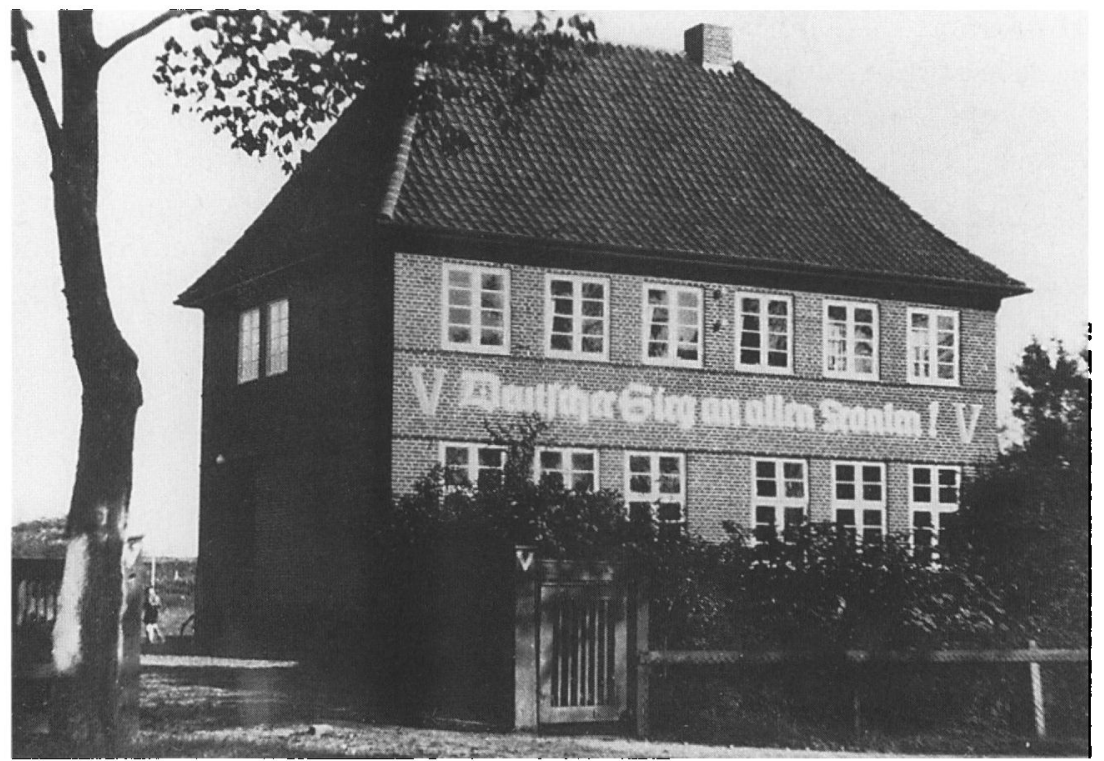

Skærbæk tyske skole set fra Ribevej under besættelsen med den prangende indskrift "Deutscher Sieg an allen Fronten!«. Foto $i$ Institut for sønderjysk Lokalhistorie.

sin våbenfrakke. Ud fra disse overvejelser gives der ordre til alle vore unge lærere i Nordslesvig om at blive på deres poster«. Han forstod udmærket, skrev han videre, at "man gerne ville deltage under våben. De, som ikke gjorde krigen 1914-18 med eller oplevede den, ser med inderlig smerte, at de heller ikke i dag kan deltage aktivt i kampen «. Der var dog mulighed for at melde sig frivilligt, sluttede han, men undervisningen måtte ubetinget fortsætte, og der ville ikke kunne udbetales løn eller familieunderstøttelse til de lærere, der meldte sig.

Alligevel gjorde de det stort set alle.

Thaysen skrev 30/5-1940 til Skoleforeningen:

Hermed melder jeg mig frivilligt til den tyske værnemagt. Heil Hitler Bruno Thaysen Den tyske skole, Skærbæk.

De øvrige breve var næsten enslydende. Af 42 mandlige lærere meldte 37 sig i løbet af få dage, og to beklagede meget, at de desværre 
ikke kunne, da den ene havde sukkersyge og den anden en leverlidelse. Alle pointerede, at de giorde det frivilligt.

En uge senere modtog Thaysen besked fra Elholm om, at Schulverein p.t. ikke så sig i stand til at undvære ham. Han står derfor ikke på listen over de lærere, der evt. kunne afses til krigstjeneste.

Den 10. februar 1941 udsendte landsfører Jens Møller et opråb til den mandlige befolkning i Sonderjylland om at melde sig til frivillig tysk krigstjeneste. »Af 77 tyske lærere (både på privat- og kommuneskolerne) inden for den pågældende aldersklasse meldte der sig 76, og heraf blev 25 fritaget for krigstjeneste«, noterede Tønder Amtstidende.

Da også Thaysen indkaldtes omkring nytår 1943, skrev Elholm til Volksdeutsche Mittelstelle i Berlin, der havde ansvaret for bl.a. de tyske skoler uden for Tyskland, og bad ham undtaget fra militærtjeneste. Han var aldeles uundværlig i Nordslesvig. Også "uden for skolen, som han vier al sin kærlighed, gør han et stort arbejde $i$ ungdomsforbundet. At han her hører til de bærende kræfter, fremgår af, at han ikke alene er amtsungdomsfører, men også stedfortrædende landsungdomsfører. Desuden er han leder af ungdomssporten (Sportsamt der Jugend)«. Han blev alligevel indkaldt $1 / 4$ og stationeret i Pressburg (Bratislava) i Slovakiet. Han blev dog efter ca. syv måneder hjemsendt og derefter ansat som skoleleder i Brunde ved Rødekro.

Lærer Gert Christiansen, Gånsager, var som dansk statsborger ikke tvunget til at gøre tysk krigstjeneste, men havde som de andre meldt sig frivilligt. Som tysk nordslesviger og lærer i den tyske skole følte han sig forpligtet til at gøre det. Han havde ikke indlagt sig de samme fortjenester som Thaysen og var derfor ikke »unabkömmlich«. Han blev indkaldt i april 1942 og sendt til østfronten. Her blev han i 1943 hårdt såret og døde $18 / 6$ på et lazaret.

\section{Skolernes afvikling}

I sommeren 1944 blev Gånsager tyske skole beslaglagt til bolig for arbejdere på den pansergrav, som værnemagten lod anlægge fra diget vest for Rejsby til østkysten. Der opsattes køjesenge i skolestuen og ungdomslokalet til de indkvarterede, som også disponerede over skolens forgang, kaffekøkkenet og elevtoiletterne. Også den danske skole blev inddraget. Ved Luthersk Missions forsamlingssal lidt nord herfor indrettedes køkken og spisesal for arbejderne. 
Det betød, at undervisningen blev midlertidigt indstillet. Selv om det ikke nævnes, er der ingen tvivl om, at skolen så hurtigt, det var muligt, videreførtes under mere primitive forhold, f.eks. i en privat stue, på samme måde som danske skoler i samme situation. I hvert fald er det sidste elevtal for skolen (12 børn) oplyst 21/11-1944, og en opgørelse over de tyske lærere i april 1945 godtgør, at lærer Mühlenhaus fortsat var ansat i Gånsager. Man kan heller ikke forestille sig, at Schulverein stiltiende ville acceptere, at skolen blev lukket, ligesom læreren næppe var blevet i Gånsager, hvis det var sket, de tyske skolers desperate lærersituation med så mange indkaldte taget $\mathrm{i}$ betragtning.

Mühlenhaus blev boende i lærerlejligheden, og efter kapitulationen 5. maj 1945 blev han sammen med de øvrige tyske lærere og mange andre fra mindretallet interneret i Fårhuslejren, den tidligere Frøslevlejr. Nøjagtig hvornår dette skete, er svært at sige, men en del af lærerne ved de tyske kommuneskoler arresteredes o. 10. maj, og nogle af privatskolernes lærere er vel blevet taget ved samme lejlighed. Man har næppe skelnet skarpt imellem dem. Det er dog senest sket i slutningen af juni, idet undervisningsministeriet 25/6-1945 udsendte et cirkulære om lukning af de tyske skoler. De skulle have "ferie indtil videre«, fordi alle læse- og lærebøger skulle gennemgås. De kunne ikke genåbnes uden skoledirektionens tilladelse. Undervisningspligten for disse skolers elever blev midlertidigt suspenderet og først genindfort ved en lov af 21/12. De blev da henvist til den danske folkeskole, men 12/7-1946 blev der igen åbnet mulighed for at oprette tyske privatskoler eller tysk hjemmeundervisning på nærmere angivne betingelser.

Den 25/5-45 spurgte formanden for skolenævnet ved Gånsager (danske) skole amtsskolekonsulent Nic. Svendsen, om man uden videre kunne optage børnene fra den tyske skole, eller man skulle vente, til der kom en endelig ordning på mindretalsspørgsmålet. Kommuneskolen var genåbnet $15 / 5$, efter at bygningen var rømmet af fæstningsarbejderne.

Denne og lignende forespørgsler fra bl.a Ballum bevirkede, at Svendsen sendte en skrivelse til samtlige sogneråd i Tønder amt. Da der foregik »indmeldelser til den danske skole af børn, hvis forældre tidligere har stillet sig bestemt afvisende over for denne skole og afgjort har sluttet sig til det tyske mindretal, hvilket klart fremgår deraf, at de frivilligt har sendt deres børn i tysk skole«, bestemte han, at 


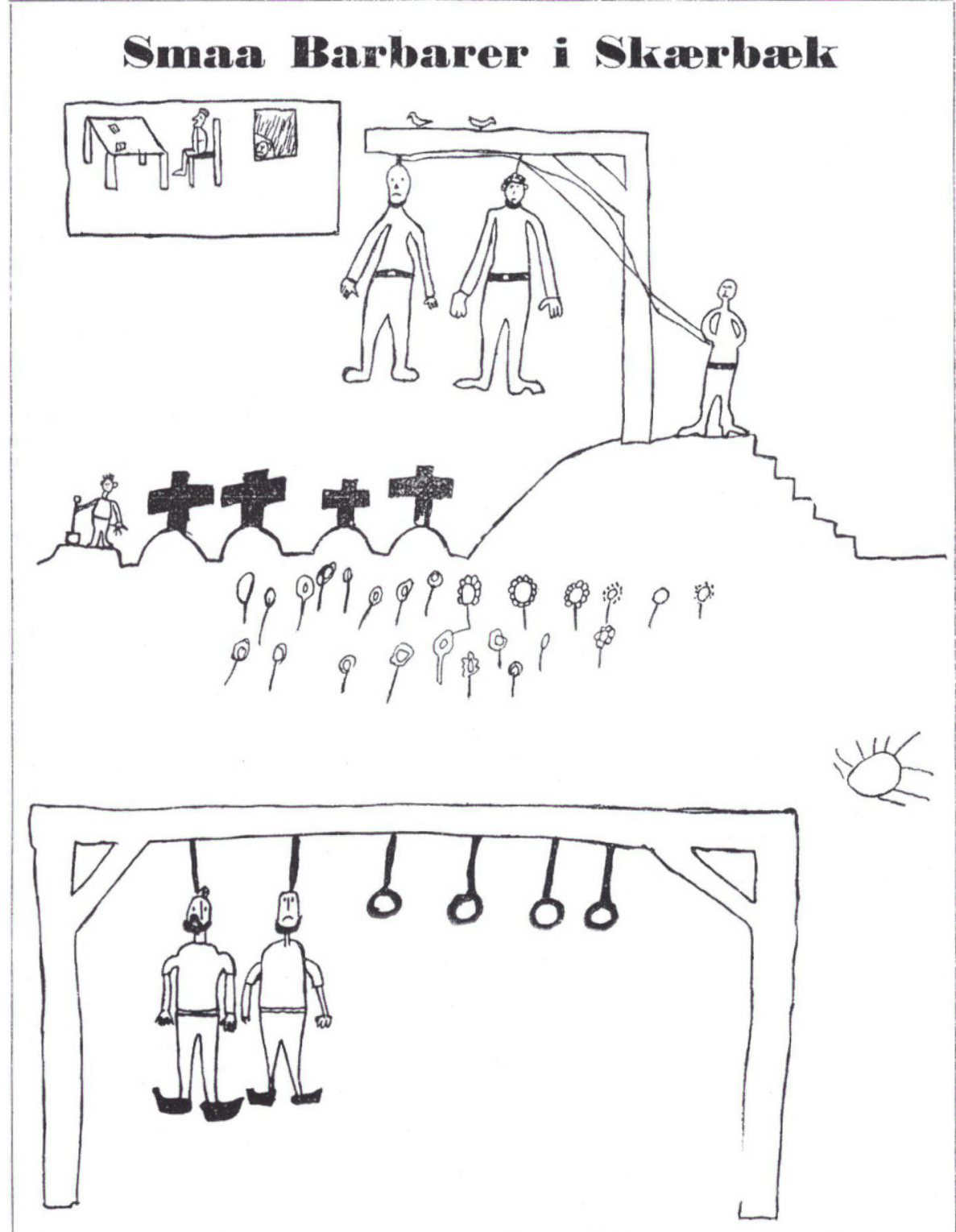

I den tyske Privatskole i Skarbak har man fundet nogle Mapper men Tegninger, der er kom. promitterende for nazistiske Opdragelsesmetoder i Almindelighed og for ovennaunte. Skole i Scerdeleshed. Vi begynder Offentliggorelsen af ud. valgte Stylker $i$ denne Serie. Elcverne er cr. 9 Aar, men som man ser allerede veludviklode Bedler. Bemcerk den klare Disposition i Retlergangen paa den store Tegning: 1. Paagribelsen, 2. Afstraffelsen og 3. Begravelsen. Arrangcmentet med Blomsterne virker rarende. Det er dog ikke a) humane Grunde, men fordi der nu engang rolsser Blomster paa en Kirkegaard. Paa den lille Trgning har Kunstneren vaset saa forsynlig at anbringe rigeligt med Lokker, saa Galgen kan of- lektuere Ordrerne, saa hurtigt de indleber. Drt er ogsaa snildt udtankt, at F jenderne falder ned af Broer og spiddps pan Pigge anbragt derunder. En sarlig Metode med Bier skal vi ogsan demonstrere.

Al denne "Kunsta or ikke skabl af Elever pao eget Initiativ, men sat i System af en nidkcer retvendt Laerer. Vi er af den Mening, at hverken han eller Sloolelederen, der har rolereret den Slags Undervisning vil kunne bruges i nogen tysk Primatshole i Fremtiden. De har forbrudt sig paa det strandigste og maa tage Konsekvensernc.

Det tyske Opdragelsesproblem er det alvorligste af alt, huad det sendrede Rige $i$ Dag og $i$ Tiden fremover har at slaas med. 
forældrene $\mathrm{i}$ hvert enkelt tilfælde skulle indsende et andragende til skolenævnet. De skulle heri klart begrunde, hvorfor de ønskede deres børn overflyttet til dansk skole. Da det nogle steder ville kunne betyde en ændring af den offentlige skoles forhold, nemlig hvis der kom mange overflytninger, skulle sognerådet, skolekommissionen og skolenævnet afgive en udtalelse, som sammen med forældrenes ansøgning indsendtes til Tønder Amts Skoledirektion (d.v.s. amtsskolekonsulenten), som så ville træffe de fornødne afgørelser.

Mühlenhaus sad i Fårhus i godt halvandet år. Efter frigivelsen flyttede han til Tønder og blev senere lærer ved den tyske skole i SædUbjerg. Thaysen kom til Wittendorf i Angel.

Skolen i Skærbæk fungerede til maj 1945. Eleverne overførtes til den danske skole. I begyndelsen blev de mobbet af såvel børnene som nogle af lærerne. »Kun førstelærer Schultz behandlede os ordentligt og på lige fod med de andre børn«, fortæller en af dem, dengang en pige på 10 år.

Begge bygninger overgik som de øvrige tyske skoler og institutioner i Sønderjylland til den danske stat $i$ henhold til loven om beslaglæggelse af tysk og japansk ejendom efter krigen. Gånsager tyske skole anvendtes i en del år af statsfængslet i Renbæk som funktionærbolig, inden den blev solgt til private. Skolebygningen i Skærbæk solgtes til Odense Ægkompagni og anvendtes til ægpakkeri, indtil den i 1970'erne overtoges af fabrikken Wiema Sko og udvidedes med en mindre produktionshal.

Siden 1945 har der ikke været tyske skoler i Gånsager og Skærbæk.

Elevtegning fra den tyske skole i Skærbæk, fundet på skolen efter befrielsen $1945 \mathrm{og}$ gengivet $i$ den sønderjyske modstandsbevagelses blad "Graenseposten" 8. februar 1946. Bemærk teksten! 


\section{GR AENSE - POST EN}

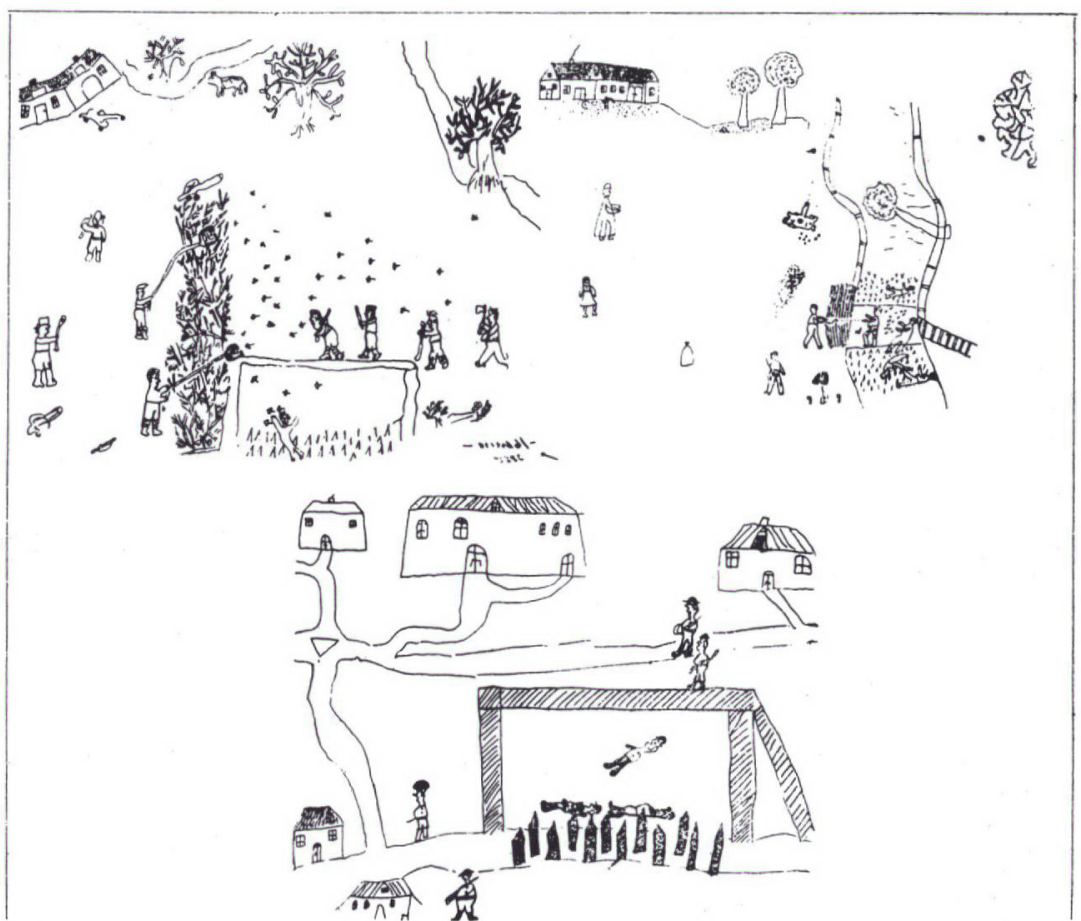

Hosstaaende Illustration er tegnet til en Historie fra Trediveaarskrigen: „Der Kampf um die Scholle (Kampen om Hjemstavnens Jord), som Eleverne har faaet læst op i Klassen. Den er ogsaa velegnet for 9 Aars Børn, hvad denne tilfældigt valgte Prøve viser.

„Fremad march! « skreg den svenske Vagtmester og sprang ned i Graven, og paa een Gang var Vandet fuldt af Svenskere; men det var, som om det var kogende, saadan skreg de op, thi enhver af dem var sprunget ned paa de spidse Pæle (๖: som de tyske Bønder forinden havde rammet ned).

»Skyd dem dog i det mindste ihjel, det er jo skrækkeligt! $\propto$ raabte Præsten; men OIdermanden rystede paa Hovedet: „Nej, det har vi ikke Tid til, og jo længere de piber dernede, jo senere vover de andre sig herhen. Gaa I nu .... og hold jer til Kvinderne og Bornene, dér er der mere Brug for jer".
Ved et følgende Angreb, er det saa, at Bierne tages i Brug som vist paa Tegningerne. Fra et Baghold paa den anden Side Broen, kan Bønderne ved Hjælp af en særlig Mekanisme slynge de smaa Uhyrer i Hovedet paa Fjenderne, der gaar fuldkommen fra Koncepterne. En Fange (en Sachser, som har sluttet sig til Fjenderne) faar en vigtig Opgave.

„Schweinehund! Egentlig skulde du dø! « raaber en af Bønderne til ham. «Men løb over og sig til Svenskerne, at de skal sørge for at komme væk. Thi vi har Bier nok og vore Venner kommer allesammen. $\mathrm{O}_{\mathrm{g}}$ hvis nogen spørger dig, hvor du har været saa sig: Hos Varulvene. Du er den første, som vi sender levende bort «. Soldaten rystede saadan, at han næppe kunde gaa over Broen, og da han kom til den anden Bred, faldt han om.

I Grænse-Posten fra 22. februar 1946 gengives denne elevtegning fra den tyske skole i Skærbæk. 


\section{Elevtal}

$\begin{array}{lll} & \text { Skærbæk } & \text { Gånsager } \\ \text { 1930: } & 27 & \\ \text { 1931: } & 25 & \\ \text { 1932: } & 26 & 14 \\ \text { 1933: } & 28 & 19 \\ \text { 1934: } & 29 & 21 \\ \text { 1935: } & 31 & 16 \\ \text { 1936: } & 31 & 18 \\ \text { 1937: } & 27 & 20 \\ \text { 1938: } & 19 & 18 \\ \text { 1939: } & 23 & 18 \\ \text { 1940: } & 20 & 17 \\ \text { 1941: } & 27 & 13 \\ \text { 1942: } & 25 & 13 \\ \text { 1943: } & 23 & 11 \\ \text { 1944: } & 19 & 12\end{array}$

Kilde: Deutscher Schulvereins arkiv nr. 252, sammenholdt med Fr. Christensen: Aufbau deutscher Schulen in Nordschleswig 1919-1940.

\section{Lærere og bestyrelsesformænd}

Skærbæk

\section{Lxrere}

1922-1923

$2 / 5-1930-30 / 9-1935$

8/10-1935 - 31/3-1936

$1 / 4-1936-31 / 3-1939$

$15 / 6-30 / 6-1936$

$1 / 4-1939-6 / 12-1943$

$1 / 4-6 / 12-1943$

$7 / 12-1943-16 / 2-1944$

$17 / 2-31 / 3-1944$

1/4-1944 - maj 1945

28/8 - 13/11-1944

$14 / 11-1944-3 / 2-1945$
Herluf Löch, vandrelærer

Andreas Vilhelm Rahlf

Helmut Hansen

Walter Hauschildt

Bruno Thaysen, vikar

Bruno Thaysen

Agnete (Netti) Schmidt, vikar

Anneliese Thomsen

Dorothea Steenholdt, vikar

Helmut Thomsen

Skolen lukket p.gr. af lærerens sygdom Hannelore Exner, vikar 
Bestyrelsesformænd

19/2-1930 - 22/4-1932

22/4-1932 - 1/4-1937

21/4-1937 - 4/4-1941

4/4-1941 - 22/4-1944

22/4-1944 - maj 1945

\section{Gånsager}

Lærere

juni 1931 - 31/3-1932

1/4-1932 - 8/4-1938

15/4-1938 - 4/10-1940

5/10-1940 - 31/3-1942

15/4-1942 - 31/3-1943

1/4-1943 - maj 1945

Bestyrelsesformænd

24/4-1932 - 1/5-1933

1/5-1932 - febr. 1934

16/4-1934 - 14/4-1935

14/4-1935 - 9/4-1942

9/4-1942 - maj 1945
Hermann Kohl, Skærbæk

Chr. Hansen (død), Kæpslund

Carl Sturm, Brøns

Anders Bech, Skærbæk

Friedrich Hagge, Skærbæk
Ludwig Claussen, vandrelærer

Lydia Wohlenberg

Käthe Jepsen Schmidt

Gert Christiansen

Anette (Netti) Schmidt

Ludwig Mühlenhaus

Nis Petersen, Gånsager

Paulsen, Hønninggård, flyttet

Heinrich Grundt, Gånsager

Anton Stenger, Frifelt

Johannes Moritzen, Gånsager

Stemmetal ved folketingsvalgene

\begin{tabular}{lllllllll}
1920 & 1924 & 1926 & 1929 & 1932 & 1935 & 1939 & $\cdot$ & 1971 \\
\hline
\end{tabular}

Skærbæk

$\begin{array}{llllllllll}\text { Tyske stemmer } & 36 & 37 & 81 & 66 & 65 & 88 & 96 & \cdot & 32\end{array}$

$\begin{array}{llllllllll}\text { Danske stemmer } & 583 & 655 & 749 & 739 & 790 & 870 & 1026 & \cdot 1749\end{array}$

$\begin{array}{llllllllll}\text { Tyske st.prc. } & 5,8 & 5,3 & 9,8 & 8,3 & 7,6 & 9,2 & 8,6 & \cdot & 1,8\end{array}$

Vodder

$\begin{array}{llllllllll}\text { Tyske stemmer } & 8 & 9 & 22 & 16 & 20 & 19 & 14 & \cdot & 6\end{array}$

$\begin{array}{llllllllll}\text { Danske stemmer } & 300 & 283 & 314 & 333 & 317 & 381 & 426 & \cdot & 456\end{array}$

\begin{tabular}{llllllllll} 
Tyske st.prc. & 2,6 & 3,1 & 6,5 & 4,9 & 5,9 & 4,8 & 3,2 & $\cdot$ & 1,3 \\
\hline
\end{tabular}

Tyske stemmer er lig med Slesvigsk Partis stemmetal. Det opstillede ikke 1943 og 1945. 1971 var sidste gang, Slesvigsk Parti opstillede selvstændigt til folketingsvalg. Som det vil ses, havde de tyske skoler ikke den helt store effekt på stemmetallene. Kilde: Aksel Lassen: Valg mellem dansk og tysk og Vestkysten. 


\section{KILDER}

Landsarkivet i Aabenraa.

Deutsche Schulverein für Nordschleswigs arkiv.

163. Gånsager skole (1932-38).

173. Skærbæk skole (1930-38).

235. Vedr. Gånsager (1939-45).

237-239. Vedr. Skærbæk (1939-45).

252. Schülerzahlen. Wehrmacht.

291. Vedr. lærere, bl.a. løn og indkaldelser.

435. Chronik der deutschen Schule zu Gonsagger bei Wodder Post Frifelt. Gegründet 19. April 1932.

436. Lærerinde frk. Wohlenbergs arkiv vedr. Gånsager skole.

437. Rechnungsbuch der deutsche Schule Gonsagger. 1932-45.

488. Skærbæk tyske privatskole 1930-44. Forskellige sager.

Bericht über die deutsche Kulturarbeit in Nordschleswig von Ostern 1930 bis Ostern 1931.

Nicolai Svendsens privatarkiv.

88. Det danske mindretal i Sydslesvig og det tyske mindretal i Nordslesvig 1924-38.

95. Tyske skoleforhold i Nordslesvig 1922-46.

Mundtlige oplysninger fra Hans Grundt, Th. Grundt, A. Lui, Hans Jorgensen, Vera Lund, Andreas Falk, Ane Konstmann, Adeline Hauschildt m.fl.

\section{Aviser og blade}

Skærbæk Avis, 1930-45.

Vestslesvigs Tidende maj-juni 1945.

Vestkysten, maj-juni 1945 og 22/9-1971.

Grænseposten. Udgivet af Frihedsbevægelsen i grænselandet 1945-46.

Øvrige henvisninger til avisomtale grundes på udklip i Deutsche Schulvereins arkiv.

\section{LITTERATUR}

Anonym (muligvis Nic. Svendsen): Det tyske Mindretal i de sønderjydske Landsdele. En kort oversigt over den danske lovgivning. Udenrigsministeriet, 1936.

Henrik Becker-Christensen: Det tyske mindretal i Nordslesvig 1920-32 I-II. Institut for Grænseregionsforskning, 1990.

Nic. Blædel: Er vor Sydgrænse truet -. Berlingske Forlag, 1935.
Fr. Christensen: Aufbau deutscher Schulen in Nordschleswig 1919-1940. Heimatkundliche Arbeitsgemeinschaft für Nordschleswig, Heft 24, 1971.

Cirkulære af 25/6-1945 om lukning af tyske skoler i Sonderjylland m.v. Undervisningsministeriet.

Andreas Grau: Mindretalsskole-Lovgivning og Praksis. Sønderjydsk Maanedsskrift, aug. 1934.

K. Edvard Larsen: Vort grænseland 194142-43. Volkung, 1942-43.

N. A. Larsen (red): Dansk Skolestat IV. Arthur Jensens Forlag, 1934.

Aksel Lassen: Valg mellem dansk og tysk. Historisk Samfund for Sonderjylland, 1976.

Annemarie Leppien og Jörn-Peter Leppien: Mädel-Landjahr in SchleswigHolstein. Wachholtz, 1989.

Arthur Lessow: Deutsche Wanderschulen in Nordschleswig 1920 bis 1923. Schriften der Heimatkundlichen Arbeitsgemeinschaft für Nordschleswig, Heft 73, 1998.

Lov af 30/3-1946 om forlængelse af midlertidig lov af 21/12-1945. Undervisningsministeriet.

Lov af 12/7-1946 om private tysksprogede skoler, tysksproget hjemmeundervisning m.m. i de sønderjyske landsdele. Undervisningsministeriet.

Midlertidig lov af 21/12-1945 om undervisning af børn, der hidtil har været undervist $\mathrm{i}$ de tysksprogede skoler $\mathrm{i}$ de sønderjyske landsdele. Undervisningsministeriet.

Johan Peter Noack: Det tyske mindretal i Nordslesvig under besættelsen. Dansk udenrigspolitisk Instituts skrifter 6, Munksgaard, 1974.

Ingrid Riese: Die deutsche Privatschule in Süderhaff, gegründet 1928. Schriften der Heimatkundlichen Arbeitsgemeinschaft für Nordschleswig, Heft 73, 1998.

Harald J. Rud: Tysk politisk og kulturelt arbejde i Nordslesvig. Sønderjyske Årbøger, 1923.

Kim Salomon: Konflikt i grænseland. Sociale og nationale modsætninger i Sornderjylland 1920-33. Gyldendal, 1980.

Nicolai Svendsen: I Genforeningens tjene- 
ste. Senderjydsk Skæbne III, Historisk Samfund for Sonderjylland, 1968.

H.E. Sørensen: Skærbæk kommuneskole gennem 250 år. Skærbæk kommuneskole, 1992.
H.E. Sørensen: Skærbæk kommune i gamle billeder. Fastlandssognene. Melbyhus, 1997.

A. Torp: Den danske mindretalsordning $i$ Sønderjylland. Politisk Årbog, 1930. 